Int. J. Dev. Biol. 62: 403-417 (2018)

https://doi.org/10.1387/ijdb.180033vb

\title{
Role of the immune response in initiating central nervous system regeneration in vertebrates: learning from the fish
}

\author{
VIKTORIA BOSAK, KEI MURATA, OLIVER BLUDAU and MICHAEL BRAND* \\ Center for Molecular and Cellular Bioengeneering (CMCB), \\ DFG-Center for Regenerative Therapies Dresden (CRTD), Technische Universität Dresden, Germany
}

\begin{abstract}
The mammalian central nervous system is not able to regenerate neurons lost upon injury. In contrast, anamniote vertebrates show a remarkable regenerative capacity and are able to replace damaged cells and restore function. Recent studies have shown that in naturally regenerating vertebrates, such as zebrafish, inflammation is a key processes required for the initiation of regeneration. These findings are in contrast to many studies in mammals, where the central nervous system has long been viewed as an immune-privileged organ with inflammation considered one of the key negative factors causing lack of neuronal regeneration. In this review, we discuss similarities and differences between naturally regenerating vertebrates, and those with very limited to non-existing regenerative capacity. We will introduce neural stem and progenitor cells in different species and explain how they differ in their reaction to acute injury of the central nervous system. Next, we illustrate how different organisms respond to injuries by activation of their immune system. Important immune cell types will be discussed in relation to their effects on neural stem cell behavior. Finally, we will give an overview on key inflammatory mediators secreted upon injury that have been linked to activation of neural stem cells and regeneration. Overall, understanding how species with regenerative potential couple inflammation and successful regeneration will help to identify potential targets to stimulate proliferation of neural stem cells and subsequent neurogenesis in mammals and may provide targets for therapeutic intervention strategies for neurodegenerative diseases.
\end{abstract}

KEY WORDS: neuro-inflammation, injury, lipid mediator, cytokine, immune cell

\section{Introduction}

Although continuous generation of new neurons occurs in the central nervous system during adulthood, mammals are not able to regenerate neurons lost upon traumatic injury, stroke or neurodegenerative diseases. In spite of extensive research, it is still not fully understood, why teleosts and amphibia such as axolotl and zebrafish, are capable of regenerating extensive parts of their body, while mammals such as human or mouse, can not (reviewed by (Kaslin et al., 2008; Tanaka \& Ferretti, 2009; Grandel \& Brand, 2013; Alunni \& Bally-Cuif, 2016; Fig. 1).

Some studies indicate that extensive neuronal regeneration has been lost in certain vertebrate species selectively and propose that this loss correlates with the development of a more complex immune system (reviewed by (Aurora and Olson, 2014). Whether or not this hypothesis holds true, remains to be experimentally addressed. Of note, zebrafish, which exhibit extensive neuronal regeneration, also possess a complex immune system (Renshaw and Trede, 2012). Until recently, inflammation following traumatic injury was considered to be mainly detrimental, especially through secondary damage to the wounded tissue mediated by a variety of inflammatory signaling molecules (recently reviewed by (Gadani et al., 2015; McKee and Lukens, 2016). However, increasing evidence indicates that inflammation also has a strong pro-regenerative role in the nervous system. In this review, we discuss the emerging role of the immune system in initiating regeneration of the central nervous system, and highlight differences between non-regenerating and naturally regenerating organisms

Abbreviations used in this paper: CNS, central nervous system; COX, cyclooxygenase; CysLT, cysteinyl leukotriene; IL, interleukin; IFN, interferon; LT, leukotriene; NPC, neural precursor cell.

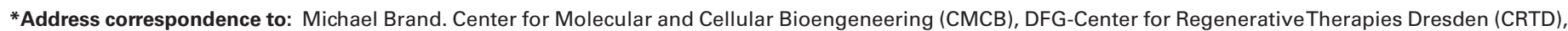

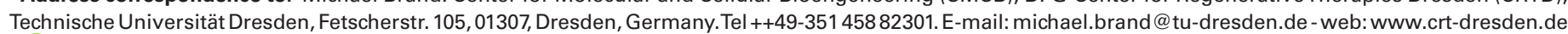
- iD https://orcid.org/0000-0001-5711-6512
}

Submitted: 13 January, 2018. Accepted: 16 January, 2018.

ISSN: Online 1696-3547, Print 0214-6282 
in the context of their immune response to injury.

\section{Constitutive and regenerative neurogenesis potentials differ between mammals and teleosts}

The vertebrate central nervous system, consisting of the brain, the spinal cord and the retina, has long being considered a static organ system, with only limited generation of new neurons during adulthood (Rakic, 1985). This view has been extensively challenged and today it is well accepted that adult neurogenesis takes place in many different species, including mammals, where it is mainly found within two specific regions in the brain: the subventricular zone (SVZ) of the telencephalic lateral ventricle and the subgranular zone (SGZ) of the dentate gyrus in the hippocampus ((Altman and Das, 1965; Doetsch and Alvarez-Buylla, 1996); recently reviewed by ((Kempermann, 2015; Gage et al., 2016)). Many factors capable of actively modulating adult neurogenesis are already known. For instance, stress and aging are stimuli that negatively affect neurogenesis (Cameron et al., 1993; Kuhn and Gage, 1996; Garthe et al., 2016), whereas environmental enrichment and physical exercise can increase formation of new neurons in the adult dentate gyrus of the hippocampus (Kempermann et al., 1997; van Praag et al., 1999). Adult neurogenesis was also confirmed in humans (Eriksson, 1998; Spalding et al., 2013), creating some hope that upon better knowledge of the required signals to activate neural stem cells, neurodegenerative diseases and tissue loss due to injury could be overcome in the future. Until today, the phenomenon of adult neurogenesis has been extensively studied in many different species and is considered to be an evolutionarily conserved trait (Lindsey and Tropepe, 2006; Kaslin et al., 2008; Kempermann, 2012; Kempermann, 2015). In contrast to mammals, teleost fish such as three-spined stickleback, gymnotiform and zebrafish possess abundant sources of neurogenesis (Zupanc et al., 1996; Ekström et al., 2001; Grandel et al., 2006). In these species, numerous neurogenic niches are distributed along the entire rostro-caudal brain axis, where continuous turnover of neurons is found until adulthood (Zupanc et al., 2005; Grandel et al., 2006; Ganz and Brand, 2016). Remarkably, besides life-long constitutive neurogenesis, teleosts are also potent regenerators following a traumatic injury (Kroehne et al., 2011; Baumgart et al., 2012; Than-Trong and Bally-Cuif, 2015; Kaslin et al., 2017).

\section{Stem and progenitor cells contribute to tissue regeneration after traumatic injury in the anamniote vertebrate central nervous system}

The regenerative potential of animals varies greatly between different species. In general, anamniote vertebrates have greater regenerative capacity compared to amniotes (reviewed by (Kaslin et al., 2008; Grandel \& Brand, 2013; Tanaka \& Ferretti, 2009; Fig. 1). Despite the fact that adult neurogenesis occurs in mammalian species, regenerative capacity is very limited. Although constitutive neurogenesis can be significantly increased by physical exercise or environmental stimuli, the number of neurons generated is usually not sufficient to replace cells lost due to injury or neurodegenerative disease (Jessberger and Kempermann, 2003; Kronenberg et al., 2003; Fabel et al., 2009).

In areas where neurogenesis is normally absent, such as the cerebral cortex and the striatum, recent studies have indicated a certain degree of reactive neurogenesis following ischemic stroke (recently reviewed by (Lindvall and Kokaia, 2015)). To address the problem of insufficient regenerative neurogenesis, astrocytes and NG2 glia reacting to injury, have become an interesting target for neuronal reprogramming strategies (for recent reviews see (Péron and Berninger, 2015; Berninger and Jessberger, 2016; Gascón et al., 2017)).

In contrast to mammals, the zebrafish has remarkable regenerative capacity and is therefore an extremely valuable model for regeneration research (see review by (Kizil et al., 2011; Gemberling et al., 2013)). To study traumatic brain injuries various lesion paradigms have been established in rodents such as weight-drop models, fluid percussion or cortical stab wound injuries (reviewed

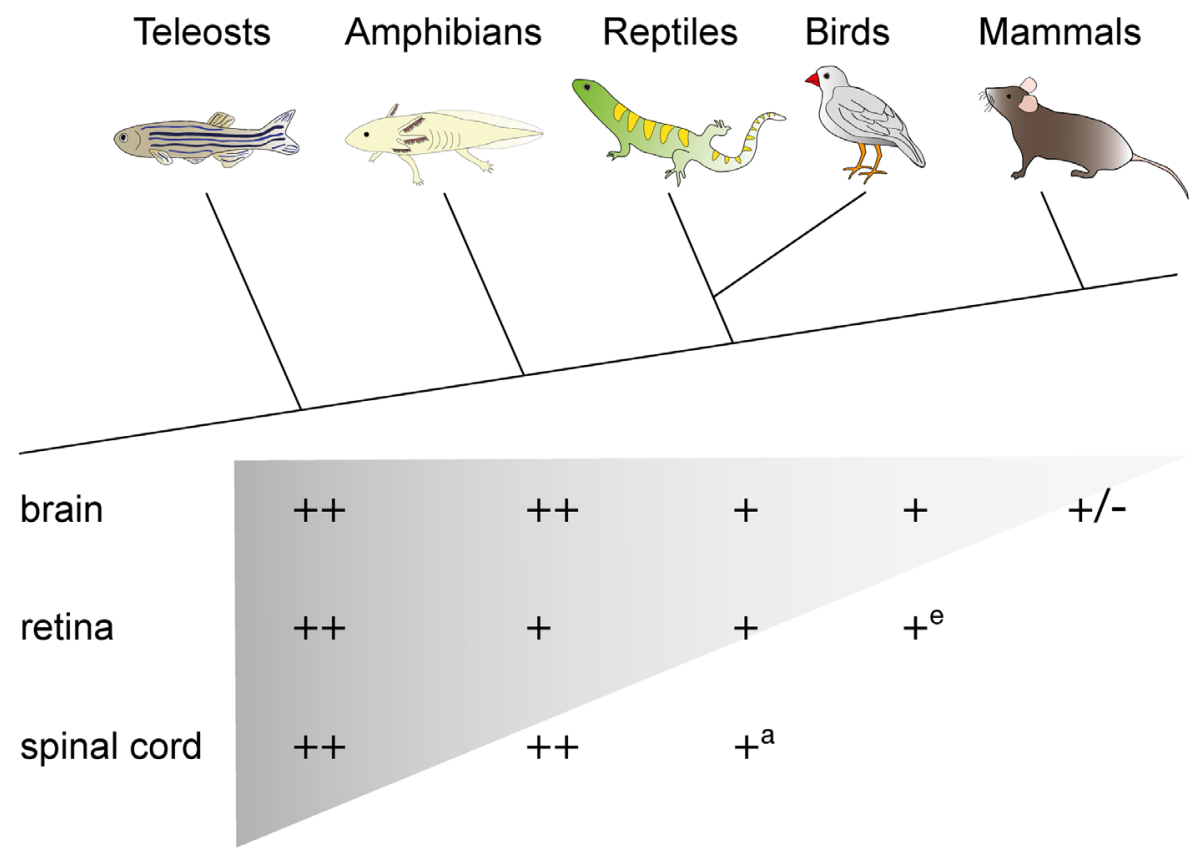

Fig. 1 Regenerative potential of the central nervous system differs across vertebrate classes. The ability to regenerate the central nervous system (CNS) varies between different vertebrate species and relates to their phylogenetic distance from each other. Regenerative potential has declined throughout evolution; Teleosts, such as the zebrafish, show extensive regeneration of the brain, retina and spinal cord. Amphibians and reptiles possess the ability to regenerate certain areas of their CNS. In reptiles, spinal cord regeneration is limited to axonal regrowth, but no longer neurogenesis $\left(+^{a}\right)$. In birds, retinae can regenerate during embryonic stages but no longer in the adult organism. Although some degree of reactive neurogenesis has been observed in the mammalian CNS, it is typically insufficient for regeneration of neurons lost to injury or disease. After Grandel and Brand, 2013, modified. ++ high regenerative potential, + regeneration, $+^{a}$ axonal regrowth, $+^{e}$ regeneration atembryonic stages, + /-neurogenesis insufficient for regeneration. Note that this denotes qualitative levels of CNS regeneration at the tissue level; regeneration competence may well differ for different cell lineages (e.g., Kaslin et al., 2017). 
by (Xiong et al., 2013); (Buffo et al., 2005)). To create a stab wound injury in the adult zebrafish telencephalon, a small cannula is introduced through the nostril into the brain parenchyma without directly targeting the ventricular zone, where the neural stem cells (radial glial cells) reside (Kroehne et al., 2011). Upon injury a quick cellular response of increased apoptosis and edema formation is observed. Radial glial cells react to injury and increase proliferation at the ventricular zone of the lesioned hemisphere, and genetic lineage tracing experiments confirmed that the daughters of radial glia differentiate into neurons that repopulate the lesion site. In addition, an increase of glial fibrillary acidic protein as well as hypertrophy of glial processes indicates reactive gliosis, however neither chronic inflammation nor scarring occurs in the adult zebrafish brain after injury (Kroehne et al., 2011). Other studies have similarly shown that the zebrafish successfully regenerates after stab wound injuries to the telencephalon via increased proliferation of radial glial cells (Ayari et al., 2010; März et al., 2011; Baumgart et al., 2012; Kishimoto et al., 2012). More recently, it has been suggested, that the stem cell pool of the adult zebrafish telencephalon may be depleted during regeneration, as some of the stem cells may directly convert to neurons, rather than undergoing symmetric and asymmetric divisions (Barbosa et al., 2015).

Similar regenerative events are reported to occur in the vertebrate retina (reviewed by (Lenkowski and Raymond, 2014; Wan and Goldman, 2016)). Mammals exhibit the lowest regenerative capacity, while non-mammalian vertebrates such as chick, amphibians and fish show higher potential. Similar to sites of continuous proliferation in the adult brain, the ciliary marginal zone (CMZ) of birds, amphibians and fish functions as stem cell niche, contributing both to adult growth of the retina and regeneration (reviewed by (Hamon et al., 2016). In amphibian retinae neuronal progenitor cells are generated by transdifferentiation of pigmented epithelial cells. During homeostasis, zebrafish Müller glia give rise to rod photoreceptors only (Raymond et al., 2006). This changes upon retinal damage: Müller glia partially de-differentiate, undergo interkinetic nuclear migration, re-enter the cell cycle and generate a single neuronal progenitor cell by asymmetric cell division. This progenitor undergoes subsequent cell divisions and forms a neurogenic cluster migrating towards the lesion site where the cells differentiate into the lost types of neurons (Nagashima et al., 2013). During regeneration, various signals involved in stress response, inflammation, gliosis and cell adhesion are required and sufficient to stimulate Müller glia proliferation (see section 6 . below for more details).

Reactive proliferation has also been observed following spinal cord injury in the zebrafish, where (ependymal-) radial glial cells start to proliferate and generate new motor neurons. Newly generated neurons mature and show signs of terminal differentiation and integration into the circuitry (Reimer et al., 2008). Radial glia migrate to the transected area of the spinal cord, where they form a "glial bridge" which supports axonal regeneration across the lesion site (Goldshmit et al., 2012). In addition, also large numbers of different types of interneurons are found after lesion. However, they are not generated from Olig2 ${ }^{+}$precursor cells but a different Pax6 ${ }^{+}$

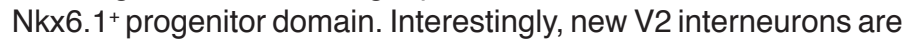
generated in a domain of the ependymal layer, which are normally not present in the unlesioned spinal cord (Kuscha, Frazer, et al., 2012). Despite the fact that zebrafish show altered serotonergic and dopaminergic innervation, locomotor function is restored after
6 weeks, indicating a high plasticity of the adult spinal network (Kuscha, Barreiro-Iglesias, et al., 2012).

\section{Immune response following central nervous system injury in mammals and non-mammalian vertebrates}

Inflammation is a rapid process following injury and involves activation of different types of immune cells. Responsive immune cells can be local, tissue-resident, self-renewing cells -such as microglia in the central nervous system- as well as peripheral monocyte-derived macrophages, neutrophils and cells of the adaptive immune system such as B cells and T cells. Circulating immune cells such as monocyte-derived macrophages, granulocytes and $T$ cells can recruit additional immune cells to the site of injury via secretion of inflammatory mediators.

Several mouse studies imply that inflammation is largely unfavorable for proliferation of neural precursor cells, a process indispensable for successful regeneration. Microglial activation in the brain reduced hippocampal neurogenesis and consistently, treatment with anti-inflammatory drugs was able to restore neurogenesis (Ekdahl et al., 2003; Monje et al., 2003). Similarly, immunosuppressive treatment was able to promote endogenous neural stem cell migration and subsequent tissue regeneration following ischemic injury. Mice recovered from cortical injury showed increased functional behavioral recovery (Erlandsson et al., 2011). Particularly in mammals, secondary damage, such as edema, impaired metabolism, reactive oxygen species as well as excitotoxicity occurring after traumatic central nervous system injury are thought to be important factors causing poor recovery (Prins et al., 2013; Corps et al., 2015). Recently, however, a novel type of dormant neural stem cell, which becomes primed but still retains its quiescent state after TBI, has been proposed. These cells can be specifically activated via IFN $\gamma$-signaling following ischemic injury (Llorens-Bobadilla et al., 2015). Interestingly, also in non-mammalian vertebrates, where regeneration occurs efficiently, a rapid inflammatory response is observed. This regenerative potential despite a strong inflammatory response appeared to be in contrast to mammals where strong, often persistent inflammation as well as formation of scar tissue from reactive astrocytes is considered one of the main obstacles for successful regeneration (Fitch and Silver, 2008; Buffo et al., 2008; Sofroniew, 2009).

In contrast to the general understanding of inflammation, it was initially surprising that in zebrafish the immune response observed after traumatic brain injury is actually required for initiating the regenerative response (Kyritsis et al., 2012). Upon drug-mediated immunosuppression, radial glial cell proliferation and subsequent regenerative neurogenesis is significantly reduced. Conversely, sterile inflammation via injection of Zymosan yeast particles into the ventricular zone of the telencephalon stimulates proliferation of radial glia and downstream generation of new neurons in the absence of injury (Kyritsis et al., 2012). Interestingly, in a different study similar results were obtained using a mouse model of optic nerve injury. Stimulation of the immune system in addition to injury led to enhanced axonal regeneration. By using intraocular Zymosan injections, monocyte-derived macrophages, neutrophils and retina-resident microglia were stimulated and consequently increased axonal regeneration in a Dectin-1 receptor-dependent manner. The authors speculate that this specific additional activation of immune cells leads to the secretion of pro-regenerative 
inflammatory mediators, which then stimulate axonal regeneration (Baldwin et al., 2015). Furthermore, immunosuppression also impaired motor neuron regeneration following spinal cord injury in the larval zebrafish (Ohnmacht et al., 2016). In the adult red spotted newt Notophthalmus viridescens, a model of neurotoxinmediated injury selectively ablates dopaminergic neurons, triggering a strong inflammatory response with recruitment and activation of microglia. The salamander fully regenerates these lesions via activation of radial-glia like ependymoglial cells, which proliferate and regenerate lost dopaminergic neurons (Parish et al., 2007; Berg et al., 2010). Interestingly, upon immunosuppression using dexamethasone, more newly generated tyrosine hydroxylase neurons are found in response to injury (Kirkham et al., 2011). It will be important to carefully dissect the immune response also in a temporal manner, since correct timing is likely one of the key factors influencing regenerative outcome. In addition, it will be crucial to further investigate underlying cellular and molecular inflammatory cues that act on neural stem cells.

\section{Immune cell types and their function during regeneration}

\section{Microglia}

Microglia, the central nervous system-resident macrophages, descend from the myeloid lineage of the hematopoietic system and colonize the brain already at early stages of development (for recent reviews, please refer to (Ginhoux and Jung, 2014; Dey et al., 2015). Despite the common progenitor origin, their developmental source seems to differ among vertebrates. In mice microglia were suggested to derive solely from the yolk sac, whereas two distinct zones of origin have been identified in the zebrafish: the rostral blood island at embryonic stages, and the ventral wall of the dorsal aorta in adulthood (Ginhoux et al., 2010; Xu et al., 2015).

Similar to other mononuclear phagocytes, such as peripheral macrophages, microglia contribute to homeostasis of the resident tissue by clearance of dying/dead cells and phagocytosis of debris and infectious agents. Under physiological conditions, although not activated, they constantly survey their microenvironment by dynamically extending processes from their cell body and show a characteristic ramified morphology. Upon detection of infection or injury, microglia undergo functional activation with morphological transformation towards an amoeboid shape. They migrate towards the infection/injury center, phagocytose infectious agents and dying cells and secrete various inflammatory mediators (for an extensive review, see (Kettenmann et al., 2011).

In a recent zebrafish study, slc7a7, a Leu/Arg transporter, has been identified to mark a specific subset of primitive macrophages, which colonize the brain and give rise to microglia during development (Rossi et al., 2015). In addition, the phosphate exporter xpr1b is required to generate microglia, also shown through a zebrafish knock-out model (Meireles et al., 2014). Mechanistically, microglial cells within the site of injury act through a variety of signals, including a wave of $\mathrm{Ca}^{2+}$ (Sieger et al., 2012). Using live-imaging, two phosphatidylserine receptors, BAl1 and TIM-4, were identified as crucial participants in the engulfment and clearing of dying neurons. BAl1 controls the formation of phagosomes around dying neurons, whereas TIM-4 is required for phagosome stabilization (Mazaheri etal., 2014). More recently, an important role of the sigma-1 receptor was suggested in microglia de-activation. The authors could show that the sigma-1 receptor is crucial to allow microglia to leave the site of injury and become inactivated (Moritz et al., 2015).

\section{Monocyte-derived macrophages}

Monocytes derive from hematopoietic stem cells, which are located in the bone marrow in mammals and in the kidney marrow of zebrafish. For detailed reviews on their developmental origin in mouse and zebrafish please refer to recent reviews by (Chen and Zon, 2009; Paik and Zon, 2010; Perdiguero and Geissmann, 2015). Monocytes from the blood stream can differentiate into macrophages and hence are termed monocyte-derived macrophages. Under central nervous system inflammatory conditions they can cross the blood brain barrier and invade the tissue. It has been shown that in mice activated macrophages can promote central nervous system repair following drug-induced demyelination by providing neurotrophic and growth factors (Miron et al., 2014). Furthermore, a population of macrophages was identified to promote regenerative axonal growth in the injured mouse spinal cord (Kigerl et al., 2009). These different phenotypes could potentially be explained by different macrophage polarization, often also referred to as activation states. Different polarization states of macrophages can be discriminated by presence of certain marker proteins. Historically, two major classes of macrophages have been proposed: "classically-activated M1" macrophages, which show increased antigen presentation capacities and expression of tumor necrosis factor- $\alpha$ (TNF- $\alpha$ ), reactive oxygen species and interleukin-1 $\beta$ (IL-1 $\beta$ ) (Block et al., 2007) and "alternatively activated M2 macrophages", which show increased phagocytic activity and secrete neurotrophic, growth and neuroprotective factors such as IL-4 and IL-13 (Ponomarev et al., 2007; Colton, 2009). Therefore, M1 and M2 macrophages could be regarded as anti- (neurotoxic) and pro-regenerative (neurotrophic) states, respectively (Tang and Le, 2016). Polarization is reversible and polarized macrophages can shift dynamically between different states. Indeed, increasing evidence suggests that there are various macrophage subsets rather than just two exclusive polarization states (reviewed by $(\mathrm{Hu}$ et al., 2014; Murray et al., 2014; Prinz and Priller, 2014)). With the zebrafish becoming a more widely used model system to study inflammation and immune processes, two different subtypes of macrophages have been reported in zebrafish as well (NguyenChi et al., 2015). Furthermore, additional markers to better classify murine macrophage subtypes have been suggested recently (Jablonski et al., 2015). However, as already mentioned, this strict binary classification might be overly simplistic and not account for the true spectrum of macrophage subtypes in vivo. A recent singlecell gene expression profiling study in mice subjected to traumatic brain injury provides evidence that monocyte-derived macrophages can not be strictly categorized into either of these classes, but rather adopt diverse polarization states simultaneously (Kim et al., 2016). In addition, great phenotypical differences in macrophage behavior have been observed between in vitro systems and in vivo studies. Hence, better nomenclature and experimental guidelines for studying macrophage activation and polarization states may help to generate comparable results (Murray et al., 2014).

A further technical limitation in studies of macrophage/microglia responses within the nervous system -both in mammals and zebrafish- has been the lack of exclusive markers to distinctly differentiate between tissue-resident microglia and monocyte-derived macrophages recruited from the blood stream. As a consequence, 
these cell types have been considered to be functionally homogenous in nervous system repair (London et al., 2013; Raposo and Schwartz, 2014). Interestingly, recent mouse transcriptome studies uncovered distinct profiles of gene expression between microglia and monocyte-derived macrophages (Gautier et al., 2012; Hickman et al., 2013; Butovsky et al., 2014; Grabert et al., 2016). In terms of the ability to experimentally differentiate between microglia and monocyte-derived macrophages, transmembrane protein 119 (tmem119) was identified as unique marker for microglia during homeostasis and injury-induced inflammation (Bennetta et al., 2016; Satoh et al., 2016).

A novel anti-inflammatory role has been attributed to a unique subset of infiltrating monocyte-derived macrophages in mouse spinal cord injury, which cannot be provided by activated resident microglia (Shechter et al., 2009; London et al., 2013; Shechter et al., 2013). A different study reported that M1 macrophages predominantly reside at the inflammatory site at early stages following central nervous system trauma and only later shift towards the M2 state (Miron et al., 2013). In a murine experimental autoimmune encephalitis model, a commonly used model for multiple sclerosis, disease progression was triggered by infiltration of monocytes. Interestingly, inhibition of monocyte recruitment blocked further progression (Ajami et al., 2011). These findings harbor a clinical implication as modulation of $\mathrm{M} 1 \mathrm{M} 2 \mathrm{2}$ ratios could potentially improve regenerative capacity of the human nervous system.

In the zebrafish less is known about the importance of microglia and macrophage subtypes during regeneration of the central nervous system. However, a contribution of macrophages to regeneration has also been reported for other organs. In the zebrafish fin macrophages are required during regeneration as depletion of macrophages greatly impairs regenerative growth. Macrophages accumulate at the transected area at around 4 days post amputation (dpa). In addition, the study provides evidence that macrophages are crucial early mediators of blastema formation (Petrie et al., 2014). Furthermore, a recent zebrafish study showed, that immune-suppressive treatment using prednisolone leads to decreased bone growth as well as impaired regeneration (Geurtzen et al., 2017). In a zebrafish model of peripheral axonal nerve injury, macrophages rapidly arrive at the lesion site where they engulf axonal debris and invade into the nerve following axon fragmentation(Rosenberg etal., 2012). Interestingly, macrophages are also important for mediation of heart regeneration in neonatal mice, which implies their functional relevance for regenerative processes also in mammalian systems (Aurora et al., 2014).

Additional research is needed to further characterize functional differences between resident microglia and blood-derived macrophages during health and disease. Zebrafish will serve as a valuable model with great intrinsic regenerative capacity and an immune system that appears to be very similar to the mammalian one.

\section{Neutrophils}

Similarly to monocyte-derived macrophages, neutrophils originate from the myeloid lineage in the bone marrow in mammals and the kidney marrow in zebrafish. Neutrophils in zebrafish also express myeloperoxidase and quickly respond to injuries such as tail transection (Lieschke et al., 2001).

Neutrophils are circulating in the blood stream under physiological conditions, but are recruited to sites of inflammation by crossing the endothelial barrier. They are amongst the earliest circulating immune cells to arrive at the injury site. Generally, they phagocytose infectious agents and lethally damaged cells as well as secrete inflammatory molecules (for a recent review see (de Oliveira et al., 2016). Compared to monocyte-derived macrophages and microglia, less is known about the functions of neutrophils during central nervous system inflammation and regeneration.

Due to their immune cell attracting properties, neutrophils are largely considered pro-inflammatory. Deleterious effects in central nervous system regeneration, damage of inflamed tissue by reactive oxygen species, disruption of extracellular environment by release of proteases and physical blocking at the epicenter of lost tissue have been attributed to neutrophils (reviewed by (Neirinckx et al., 2014)). Indeed, several studies have highlighted evidence for their detrimental effects. Co-culture experiments suggested neurotoxicity induced by cell-cell interactions between neutrophils and neurons (Dinkel et al., 2004). An antibody-based neutrophil depletion experiment in mice led to reduced edema formation and tissue loss after traumatic brain injury (Kenne et al., 2012). These studies indicate that neutrophils are negative effectors during regeneration. However, increasing evidence also suggests their -at least indirect- beneficial roles. In a different study, antibody-mediated neutrophil-depletion caused elevated levels of macrophage inflammatory protein $1-\gamma$ and worsened behavior outcome after spinal cord injury in mice, potentially by interfering with infiltration of other immune cells (Stirling et al., 2009). Another study found the importance of secreted leukocyte protease inhibitor for recovery of spinal cord injury (Ghasemlou et al., 2010). The many different roles for neutrophils during zebrafish regeneration as well as available tools to study their function have been thoroughly reviewed elsewhere (Keightley et al., 2014). Zebrafish in vivo studies have not only shown that neutrophils migrate to the site of injury or inflammation in a directed manner but also undergo reverse migration to find their way back to the vasculature in order to resolve acute inflammation (Mathias et al., 2006; Starnes and Huttenlocher, 2012). Interestingly, macrophages interact with neutrophils at the wound site. Redox-regulated Src family kinase signaling leads to macrophage attraction and triggers subsequent reverse migration of neutrophils through direct interaction with each other, indicating their role in regulating resolution of inflammation (Tauzin et al., 2014). Experiments using intravital imaging and electron microscopy showed that neutrophils were absent in the brain under physiological conditions as well as after neuron-specific cell ablation, leading to the conclusion that neutrophils do not contribute to brain inflammation in the larval zebrafish (van Ham et al., 2014). Their contribution to adult zebrafish brain regeneration has not been investigated so far. During optic nerve regeneration in zebrafish, neutrophils were identified as a source of oncomodulin, a mediator actively promoting regeneration. Interestingly, although macrophages are also recruited to the injury site at later stages, in absence of neutrophils they remained insufficient for regeneration (Kurimoto et al., 2013).

In light of these findings, the context-dependent role for neutrophils in regeneration of nervous system injuries remains to be further studied to better understand their potential contribution to tissue regeneration.

\section{T lymphocytes}

Tlymphocytes or T cells are part of the adaptive immune system and participate in central nervous system inflammation after trauma. 
In contrast to their presence in peripheral inflammatory tissues, presence in the central nervous system is considerably lower (Moalem et al., 1999; Stirling and Yong, 2008; Beck et al., 2010). Increasing evidence suggests a functional correlation between T lymphocytes and the nervous system, both during homeostasis and pathology (Ellwardt et al., 2016). T cells are important for adult neurogenesis and learning in rodents. Severe combined immune deficient mice (SCID mice) show poor hippocampal neurogenesis, a deficit that is restored following CD4+ $\mathrm{T}$ lymphocyte transplantation (Ziv et al., 2006; Wolf et al., 2009).

Similar to other immune cells, effects of T cells on neural repair seem to be contradictory: both deleterious and beneficial roles have been reported. T cells isolated from spinal cord-injured rats induced neurological deficits and histopathologic alterations in recipient animals (Popovich et al., 1997). Transgenic mice immunized against a central nervous system-derived antigen show increased neurogenesis in the hippocampus and improved learning (Ziv et al., 2006). Targeted depletion of $\mathrm{CD}^{+} \mathrm{T}$ cells in mice caused elevated recovery of motor function in a neurodegenerative multiple sclerosis model (Howe et al., 2007). In contrast to these studies, pro-regenerative/neuroprotective roles for T cells have been reported both in vitro and in vivo. Organotypic murine hippocampal slice cultures showed that $\mathrm{CD}^{+}$and $\mathrm{CD}^{+}{ }^{+} \mathrm{T}$ lymphocytes isolated from peripheral lymph nodes protect neurons from excitotoxic damage and after glucose/oxygen depletion (Shrestha et al., 2014). T cells have been reported to produce neuroprotective molecules such as brain derived neurotrophic factor (Kerschensteiner et al., 1999). There is also an indirect effect of T cells likely to be mediated via interaction with monocyte-derived macrophages or astrocytes (Garg et al., 2009; Walsh et al., 2014). Increasing evidence suggests that peripheral immune cells coming to the brain via the blood stream positively influence adult neurogenesis in the rodent hippocampus (recently reviewed by (Leiter et al., 2016)). As discussed above, monocyte-derived macrophages and microglia have functionally different subtypes. The peak of alternatively activated macrophages coincides with that of T cell infiltration into the murine nervous system (Popovich et al., 1996; Miron et al., 2013). In addition, one of the key factors triggering the alternative activation of monocyte-derived macrophages is IL-4, a prototypical T cell-derived cytokine. It has been reported that IL-4 helps to improve survival of primary murine cortical neurons under oxidative stress. IFN- $\gamma$ secreted by $\mathrm{T}$ cells also plays a neuroprotective role through stimulating astrocytes to clear neurotoxic glutamate under oxidative stress. Therefore, these findings suggest that $T$ cells activate and lead macrophages towards an anti-inflammatory phenotype, thus promoting nervous system recovery (Garg et al., 2009). Along these lines, 'protective autoimmunity' has been proposed as a central physiological mechanism for protection, repair and maintenance. The choroid plexus has been described as unique neuro-immunological gate allowing controlled entry of immune cells into the brain parenchyma (Schwartz and Baruch, 2014). As discussed above, central nervous system-specific $\mathrm{T}$ cells also show the ability to recruit monocytederived macrophages to the injured murine spinal cord where they secrete anti-inflammatory mediators to limit spread of tissue damage (Shechter et al., 2009). Although T cells have been identified in the zebrafish, their functional role in mediating regenerative processes remains unclear and warrants future research (Langenau etal., 2004; Langenau and Zon, 2005). The recent development of an immunedeficient zebrafish line similar to existing immune-compromised models in mice will be of major help in delineating the role of T cells during regenerative processes (Moore et al., 2016). Taken together, $T$ cells have a multi-faceted role in nervous system injury and they remain an interesting target for future scientific investigations to enhance tissue regeneration.

\section{Molecular cues and inflammatory mediators after injury and during regeneration}

In order to understand regeneration, not only cellular responses, but also underlying molecular mechanisms and signals triggering inflammation have to be investigated. Upon injury of the central nervous system, the immune system quickly responds, leading to activation and proliferation of microglia and attraction of additional immune cells from the blood stream. Recruitment of different inflammatory cell types as well as stimulation of cell proliferation is mediated via a variety of different secreted mediators, such as cytokines and chemokines as well as lipid mediators, which will be discussed in the following sections. Important immune-derived factors already known to stimulate neural stem cell proliferation and neuronal differentiation have been summarized in Table 1.

\section{TABLE 1}

\section{INFLAMMATORY MEDIATORS AFFECTING CENTRAL NERVOUS SYSTEM PROLIFERATION}

\begin{tabular}{|c|c|c|c|c|}
\hline Mediator & Cell type / tissue & Organism & Effect & Reference \\
\hline IL-1 $1 \beta$ & astrocytes & mouse & increased proliferation & (Liberto et al., 2004) \\
\hline TNF- $\alpha$ & $\begin{array}{l}\text { neural precursor cells, hippocampus } \\
\text { Müller glia, retina }\end{array}$ & $\begin{array}{l}\text { mouse } \\
\text { zebrafish }\end{array}$ & $\begin{array}{l}\text { deletion of TNF-receptor } 1 \text { increases neural precursor cell proliferation } \\
\text { induces proliferation }\end{array}$ & $\begin{array}{l}\text { (losif et al., 2006) } \\
\text { (Nelson et al., 2013) }\end{array}$ \\
\hline IFN-y & neural precursor cells & mouse & activation of dormant quiescent cells in response to injury & (Llorens-Bobadilla et al., 2015) \\
\hline IL-6 & $\begin{array}{l}\text { Müller glia, retina } \\
\text { retinal ganglion cells } \\
\text { spinal cord }\end{array}$ & $\begin{array}{l}\text { zebrafish } \\
\text { mouse } \\
\text { mouse }\end{array}$ & $\begin{array}{l}\text { increased proliferation } \\
\text { axon regeneration optic nerve } \\
\text { improved functional recovery }\end{array}$ & $\begin{array}{l}\text { (Zhao et al., 2014; Elsaeidi et al., 2014) } \\
\text { (Leibinger et al., 2013) } \\
\text { (Yang et al., 2012) }\end{array}$ \\
\hline CNTF & Müller glia, retina & zebrafish & induces proliferation & (Elsaeidi et al., 2014; Zhao et al., 2014) \\
\hline SDF-1 & spinal cord & rat & decreased apoptosis, increased proliferation, increased functional recovery & (Zendedel et al., 2012) \\
\hline IL-4 & $\begin{array}{l}\text { radial glial cells, telencephalon } \\
\text { subventricular zone, brain }\end{array}$ & $\begin{array}{l}\text { zebrafish } \\
\text { mouse }\end{array}$ & $\begin{array}{l}\text { increased proliferation } \\
\text { keeps neural precursor cells in undifferentiated state }\end{array}$ & $\begin{array}{l}\text { (Bhattarai et al., 2016) } \\
\text { (Perez-Asensio et al., 2013) }\end{array}$ \\
\hline CCL11 & hippocampus & mouse & decrease of neural precursor cells proliferation, impaired learning/memory & (Villeda et al., 2011) \\
\hline $\mathrm{LTC}_{4}$ & telencephalon & zebrafish & increased radial glial cell proliferation & (Kyritsis et al., 2012) \\
\hline CysLT & neural precursor cells, hippocampus & mouse & inhibiting proliferation, improved learning and memory upon inhibition & (Marschallinger et al., 2015) \\
\hline
\end{tabular}

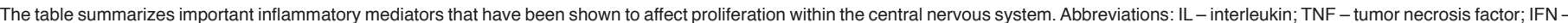

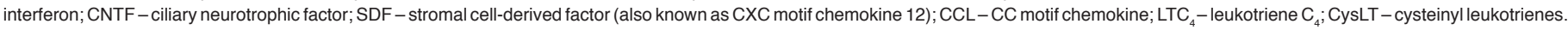




\section{Cytokines, chemokines and their receptors}

One important property of cells in general, but immune cells in particular, is their ability to secrete small molecules such as growth factors, chemokines and cytokines. Cytokine signaling appears to be evolutionary conserved, with high degrees of homology between different mammalian species, but a relatively low sequence-based homology between fish and mammals. Still, most factors do have functionally equivalent orthologs in fish (reviewed by (Savan and Sakai, 2005)). Cytokines can have a variety of functions, depending on amount, but also location and timing of production. Upon any inflammatory response several key cytokines are rapidly secreted, such as Interleukin-1 $\beta$ (IL-1 $\beta$ ), tumor necrosis factor alpha (TNF- $\alpha$ ), CXCL8/interleukin-8 (IL-8). II-1 $\beta$ reduces murine neural stem cell proliferation both in vitro and in vivo (Wang et al., 2007; Mathieu et al., 2010). Upon injury of the brain, IL-1 $\beta$ is quickly produced by activated microglia. Subsequently, mammalian astrocytes become reactive and increase their proliferation (Liberto et al., 2004). In zebrafish, where inflammation is required for initiating the regenerative response, up-regulation of IL-1 $\beta$ is observed very early following a traumatic brain injury (Kyritsis et al., 2012).

Traditionally, cytokines have been grouped into being pro- or anti-inflammatory correlating with different states of macrophage activation. However, recent studies indicate that depending on the specific context this categorization might be overly simplistic. IL-6, initially classified as pro-inflammatory cytokine, also has antiinflammatory properties depending on the type of receptor being expressed either in a membrane-bound or soluble form (Scheller et al., 2011). IL-6 is a pleiotropic cytokine, with multiple inflammatory effects. In the mammalian central nervous system, IL-6 as well as its receptors are found expressed by both neuronal and glial cell populations (Erta et al., 2012; Gruol, 2015). IL-6 is part of the neuropoietic family of cytokines, including other factors such as ciliary neurotrophic factor (CNTF), leukemia inhibitory factor, oncostatin M, cardiotrophin-1 and IL-11 (Taga and Kishimoto, 1997). Importantly, members of this family are involved in different biological processes and responses elicited by different members can be very similar. This is possible due to a very high similarity in their three-dimensional conformation, rather than primary structural similarity, which is as low as 30\% (Gadient and Otten, 1997). In vitro experiments showed that IL-6 greatly reduces murine neurogenesis and that blocking IL-6 can fully restore hippocampal neurogenesis (Monje et al., 2003). Despite the fact that zebrafish IL-6 shows a low sequence homology with other species, it has a high structural similarity to human IL-6. IL-6 family cytokines together with leptin are potent stimulators of Müller glia cell reprogramming and retina regeneration in zebrafish. It was shown that leptin, in conjunction with the gp130-coupled cytokine receptor, activate JAK/STAT signaling, which triggers Müller glia cell proliferation in the retina. Importantly, IL-6 as well as IL-11 and CNTF synergize to induce Müller glia cell proliferation also in the uninjured retina (Zhao et al., 2014). Furthermore, the same family of cytokines also stimulates activation of JAK/STAT signaling in retinal ganglion cells to facilitate optic nerve regeneration (Elsaeidi et al., 2014).

TNF- $\alpha$ is rapidly produced following traumatic injury. TNF- $\alpha$ exists in two different isoforms in the nervous system: a soluble and a transmembrane form (McCoy and Tansey, 2008; Probert, 2015). It signals via the TNF receptors 1 and 2 (TNFR-1, TNFR-2) and can activate multiple downstream signaling pathways such as $\mathrm{NFKB}, \mathrm{JNK}, \mathrm{MAPK}$ or caspase-mediated death signaling (reviewed by (Wajant et al., 2003)). A recent study found that induced inflammation via exogenous supply of TNF- $\alpha$ to mammalian astrocytes promotes their conversion to neural precursor cells via activation of NFKB signaling in vitro (Gabel et al., 2015). In a zebrafish model of retinal injury, TNF- $\alpha$ signaling is an important mediator. Dying cells secrete TNF- $\alpha$, which stimulates Müller glia to proliferate and regenerate the injured tissue (Nelson et al., 2013). In addition, factors such as TGF- $\beta$ also trigger Müller glia cell proliferation (Lenkowski et al., 2013). Based on RNA sequencing analysis of lesion stimulated Müller glia, NFKB signaling shows a high activity during zebrafish retina regeneration (Sifuentes et al., 2016). In chicken, the activation of glucocorticoid receptors using Dexamethasone was also shown to reduce the number of Müller glia derived progenitor cells after neurotoxic ablation of neurons, further demonstrating an involvement of inflammation in regeneration (Gallina et al., 2014).

IL-10 is well known for its anti-inflammatory actions, which are mediated via STAT3 activation (Murray, 2005; Bazzoni et al., 2010). IL-10 is a potent inhibitor of IL-1, IL-6, IL-10 itself, IL-12, IL-18 and TNF- $\alpha$. It not only inhibits the production of pro-inflammatory, but also augments the production of anti-inflammatory mediators including soluble TNF- $\alpha$ receptors and IL-1 receptor antagonist. Using a rat model of traumatic brain injury, exogenously administered IL-10 improved neurological outcome and reduced TNF- $\alpha$ expression. It was suggested that IL-10 is anti-inflammatory due to its regulatory effect on pro-inflammatory cytokine expression (Knoblach and Faden, 1998). IL-10 reduces neuronal differentiation and keeps precursors in an immature state. Consistently, blockage of IL-10 in vivo results in increased incorporation of newly formed neurons in the olfactory bulb of mice (Perez-Asensio et al., 2013). This indicates again that precise timing of cytokine secretion during regeneration is very important as IL-10 is required during the phase of stem cell proliferation but needs to be down-regulated to allow newly generated cells to differentiate into neurons.

The cytokine IL-4 is involved in wound healing and induction of alternatively activated macrophages (M2), which promote tissue remodeling and healing (reviewed by (Mosser \& Edwards, 2008)). IL-4 signals through its cognate receptor propagating the signal through a series of phosphorylation steps via receptor-associated kinases. The IL-4R $\alpha$ chain can also function in complex with the IL-13R $\alpha$ (Nelms et al., 1999). IL-4, which can be secreted by meningeal $T$ cells, has been positively correlated with cognitive performance. IL-4 deficient mice show cognitive deficits and impaired learning (Derecki et al., 2010). Furthermore, genetic knockout of IL-4 leads to worse outcome after stroke accompanied by larger lesion volumes. Administration of exogenous IL-4 reverses this effect (Xiong et al., 2011). Recently, using a zebrafish model of amyloid deposition in the brain, IL-4 was identified to stimulate radial glial cell proliferation and subsequent neurogenesis (Bhattarai et al., 2016). These studies indicate a beneficial role for IL-4 signaling in the context of traumatic brain injury, neural precursor cell proliferation and neurogenesis.

Chemokines are small cytokines usually involved in the induction of chemotaxis of cells. The chemokine network is very well conserved in evolution. A large comparative study investigated the evolution and development of the chemokine system in important model organisms including the zebrafish. In comparison to other species, zebrafish have a high number of chemokines and receptors, 63 and 24 respectively, probably as a result of ancient genome duplication (DeVries et al., 2006). 
The chemokine CXCL8, also known as IL-8, is one of the cardinal pro-inflammatory cytokines up-regulated during inflammation and after injury. It is secreted by glial cells, macrophages and endothelial cells and mediates activation and chemotaxis of neutrophils (Hammond et al., 1995). It is also rapidly detected in cerebrospinal fluid of TBI patients together with elevated levels of IL-6, IL-10 and TGF- $\beta$ (Kossmann et al., 1997; Mussack et al., 2002). In zebrafish, two homologs for IL-8 exist, CXCL8a and CXCL8b. Using an in vivo imaging approach, it was shown that in the absence of CXCL8, neutrophil migratory speed towards a peripheral wound was increased, directionality of movement however was not affected (Oehlers et al., 2010; de Oliveira et al., 2013).

The chemokine C-C motif ligand 2 (CCL2), also referred to as monocyte chemoattractant protein 1 , has been identified as a neuron-derived pro-regenerative chemokine in the dorsal root ganglion in rodents (Kwon et al., 2015). CCL2 can activate macrophages through interaction with its primary receptor CCR2 to produce pro-regenerative factors that can promote neurite outgrowth of cultured dorsal root ganglion neurons (Kwon et al., 2013; Kwon et al., 2016). Overexpression of the chemokine in uninjured murine dorsal root ganglion leads to accumulation of macrophages and promotes neurite outgrowth in dorsal root ganglion explants. The observed regenerative response is regulated in a STAT3-dependent manner (Niemi et al., 2016).

Both the chemokine receptor CXCR4 and its ligand CXCL12, also known as stromal cell-derived factor 1 (SDF-1), are expressed in the ventricular zone of the adult zebrafish brain and have been suggested to play a role during homeostatic neuronal migration (Diotel et al., 2010). SDF-1 can be induced by a variety of proinflammatory stimuli, such as bacterial toxins, TNF or IL-1. Also, the SDF-1/CXCR4 receptor pathway is important for homing of neural stem cells towards an injury site within the mammalian brain (Imitola et al., 2004). Our own previous research identified cxcr5 as important chemokine receptor involved during zebrafish telencephalon regeneration. In the adult zebrafish telencephalon cxcr5 is expressed by proliferating and non-proliferating radial glial cells, as well as by neurons in the periventricular region. Cxcr5 mediates neuronal differentiation of newly generated precursor cells following a stab lesion (Kizil et al., 2012). Regulation of TGF$\beta$ has recently been demonstrated as an important aspect during zebrafish retinal regeneration. TGF- $\beta$ is rapidly induced after acute light lesion, but also very quickly down-regulated. From 8-36 hours post lesion the suppressor transforming growth-interacting factor is up-regulated. Conversely, disruption of TGF- $\beta$ co-repressors leads to reduced proliferation and decreased cone photoreceptor regeneration (Lenkowski et al., 2013). Similarly, a recent study also showed that pharmacological suppression of the TGF- $\beta$ pathway could accelerate zebrafish retinal regeneration (Tappeiner et al., 2016). Both studies indicate that temporally and spatially controlled expression of mediators is crucial for proper regeneration.

\section{Non-protein and lipid-derived inflammatory mediators}

In addition to cytokines and growth factors, lipid-derived molecules are important mediators of inflammation (reviewed by (Serhan et al., 2008). Lipid mediators are involved in many different inflammatory responses, both during infection and following injury. These mediators are mostly synthesized from arachidonic acid, which is derived from cell membranes via the action of phospholipase $A_{2}$ (Farooqui et al., 2000). Subsequently, arachidonic acid can undergo a variety of reactions yielding different classes of lipid mediators. Arachidonic acid can be further oxidized via different enzymatic routes: Cyclooxygenases-1 and -2 (COX-1, COX-2) form prostaglandins and thromboxanes, lipoxygenases (LOX) form leukotrienes and lipoxins and cytochrome P450 enzymes (CYP450) form eicosatrienoic acids (EETs) (reviewed by (Dennis and Norris, 2015)). Afurther type of lipid mediators are protectins and resolvins, which exert neuroprotective effects both in the mammalian brain and retina (Bazan, 2005b; Bazan, 2014; Dyall, 2015).

In general, COX-1 is required for homeostatic and housekeeping functions, whereas COX-2 becomes rapidly activated upon inflammation and is induced by growth factors, cytokines or bacterial toxins. However, COX-2 is also constitutively found in kidney and brain (Rouzer and Marnett, 2008). COX-1 and COX-2 share approximately $60 \%$ homology at the cDNA and amino acid level. They have very similar structural and kinetic properties, the conformation of substrate binding sites and catalytic centers are highly similar. Multiple putative regulatory sites have been proposed for inducible COX-2, including the cyclic AMP, IL-6, NFKB, Sp-1, GATA-1 and glucocorticoid response elements (Phillis et al., 2006). Furthermore, expression can also be induced via IL-1 $\beta$ resulting in elevated levels of prostaglandin $E_{2}\left(P_{G E}\right)$ in the central nervous system (Bazan, 2001). Prostaglandin-mediated signaling is propagated through specific receptors leading to activation of multiple intracellular signaling cascades (reviewed by (Ricciottiand Fitzgerald, 2011)). COX-2 expression in the brain has been linked to regulation of synaptic activity, but also the perception of pain (Bazan, 2005a; Phillis et al., 2006). Inhibition of COX-2 improves cognitive function in a rat model of diffuse traumatic brain injury (Cernak et al., 2002). In contrast, in a different study treatment with a selective COX-2 inhibitor following trauma worsened motor behavior (Dash et al., 2000). Using a rat model of peripheral nerve injury, treatment with a selective COX-2 inhibitor accelerated functional recovery (Cámara-Lemarroy et al., 2008). Such seemingly contradicting studies show that the specific role of COX-2 in the context of traumatic brain injury is complex and only incompletely understood. Cyclooxygenases have been attractive drug targets for a variety of indications due to the plethora of roles they fulfill during physiologic as well as pathologic processes. Many different drugs already exist, however their potentially beneficial role in mediating neuro-inflammation following TBI is currently revisited in several pre-clinical and clinical studies (Hurley et al., 2002; Gopez et al., 2005).

Importantly, COX genes were found to be evolutionarily conserved in vertebrates. In zebrafish, COX-2 has two paralogs, COX2a (ptgs2a) and COX-2b (ptgs2b) (Grosser et al., 2002) and studies indicate that both genes generate functional and inducible enzymes upon inflammatory stimulation and have similar functions (Ishikawa et al., 2007). Prostaglandins, in particular prostaglandin $\mathrm{E}_{2}\left(\mathrm{PGE}_{2}\right)$, was investigated regarding its role in hematopoietic stem cells and found to be an important modulator of Wnt signaling (North et al., 2007; Goessling et al., 2009). This interaction is also conserved in other species, such as mice, where $\mathrm{PGE}_{2}$ is involved in hematopoietic stem cell homing and bone marrow repopulation following irradiation. In addition, the modulatory function of prostaglandins is required during liver regeneration (Goessling et al., 2009). Prostaglandins have also been proposed to exert a regulatory effect on cytokine synthesis, because $\mathrm{PGE}_{2}$ and $\mathrm{PGI}_{2}$ reduced TNF- $\alpha$ and increased IL-10 levels in murine peritoneal macrophages (Shi- 
nomiya et al., 2001). A recent mouse study reported the beneficial effect of increased prostaglandin synthesis during regeneration by blocking 15-hydroxyprostaglandin dehydrogenase (15-PGDH), a prostaglandin-degrading enzyme. Interestingly, several organs, such as bone marrow, liver and colon showed increased ability to sustain damage as well as enhanced regenerative responses. Hence, 15-PGDH negatively regulates regenerative capacity in multiple organs and presents an attractive drug target for future therapies (Zhang et al., 2015). However, its role during central nervous system regeneration remains to be addressed.

The other important branch of the arachidonic acid pathway results in the production of leukotrienes. Lipoxygenases can generate the intermediate leukotriene $A_{4}\left(L_{T A}\right)$, which is metabolized to $L_{T B}$ or $\mathrm{LTC}_{4}, \mathrm{LTD}_{4}, \mathrm{LTE}_{4}$, collectively known as cysteinyl leukotrienes (Funk, 2001). Cysteinyl leukotrienes are rapidly produced in excess following traumatic brain injury, mainly by neutrophils but also by glial and neuronal cell types (Farias et al., 2009). Pharmacological inhibition of cysteinyl leukotriene synthesis, leads to a reduction of secondary injury and cognitive impairments (Corser-Jensen et al., 2014). Blocking cysteinyl leukotriene receptors increases neural precursor cell proliferation in vitro (Huber et al., 2011) and significantly increased hippocampal neurogenesis leading to improved learning and memory in aged mice. Knock-down experiments identified the GPR17 receptor to be critical for mediating this effect (Marschallinger et al., 2015).

Our own studies identified cysteinyl leukotriene receptor 1 (CysLTR1)-LTC 4 signaling as a crucial component of the neuroregenerative response in the zebrafish telencephalon. Using a selective receptor antagonist, both radial glial cell proliferation as well as subsequent neurogenesis in the brain parenchyma are diminished. Conversely, supply of exogenous LTC $_{4}$ in complete absence of injury increases both stem cell proliferation as well as neurogenesis in the adult zebrafish telencephalon. Furthermore, $\mathrm{LTC}_{4}$ supply alone is sufficient to activate the regeneration specific transcription factor gata3 in radial glial cells of the ventricular zone (Kyritsis et al., 2012). A different study also reported that immunosuppressive treatment using dexamethasone significantly reduces cardiac repair after injury in the adult zebrafish (Huang et al., 2013).

Many studies suggest that inflammation is beneficial for healing and regeneration only if the initial inflammatory response does not persist or becomes chronic but is rapidly resolved. Many studies investigate the role of pro-resolving lipid mediators such as lipoxins, resolvins and protectins and their role in actively terminating an inflammatory response (for a review see (Serhan et al., 2008)). It is important to emphasize that these mediators are not antiinflammatory or immunosuppressive but rather activate specific mechanisms required to regain tissue homeostasis. Pro-resolving mediators increase monocyte recruitment to help faster clearing of cell debris and dead cells by phagocytosis. In a mouse stroke model, neuroprotectin D1 exerts neuro-protective effects both in vivo and in vitro via inhibition of leukocyte infiltration, NFKB signaling and COX-2 induction (Marcheselli et al., 2003). Furthermore, this mediator also has protective functions in a model of corneal injury, where it potently increased nerve regeneration (Cortina et al., 2013). Upon traumatic brain injury, lipoxin $A_{4}$ is a potent negative regulator of pro-inflammatory cytokine secretion. In addition, lipoxin $\mathrm{A}_{4}$ treatment attenuates blood brain barrier breakdown, brain edema and lesion volume (Luo et al., 2013). injury
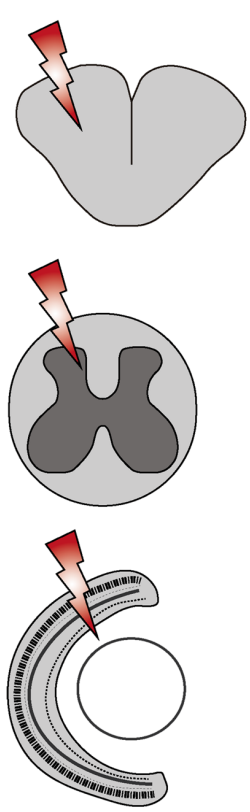

inflammation
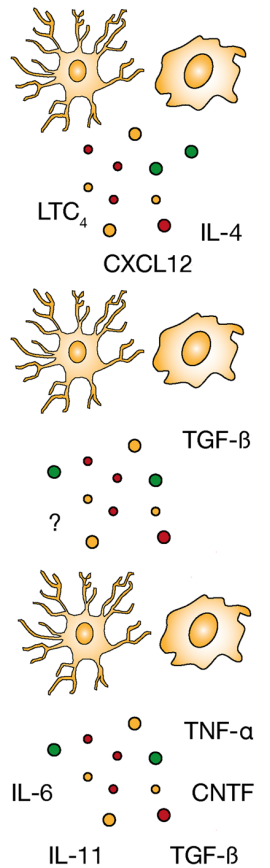

stem cell activation \& proliferation
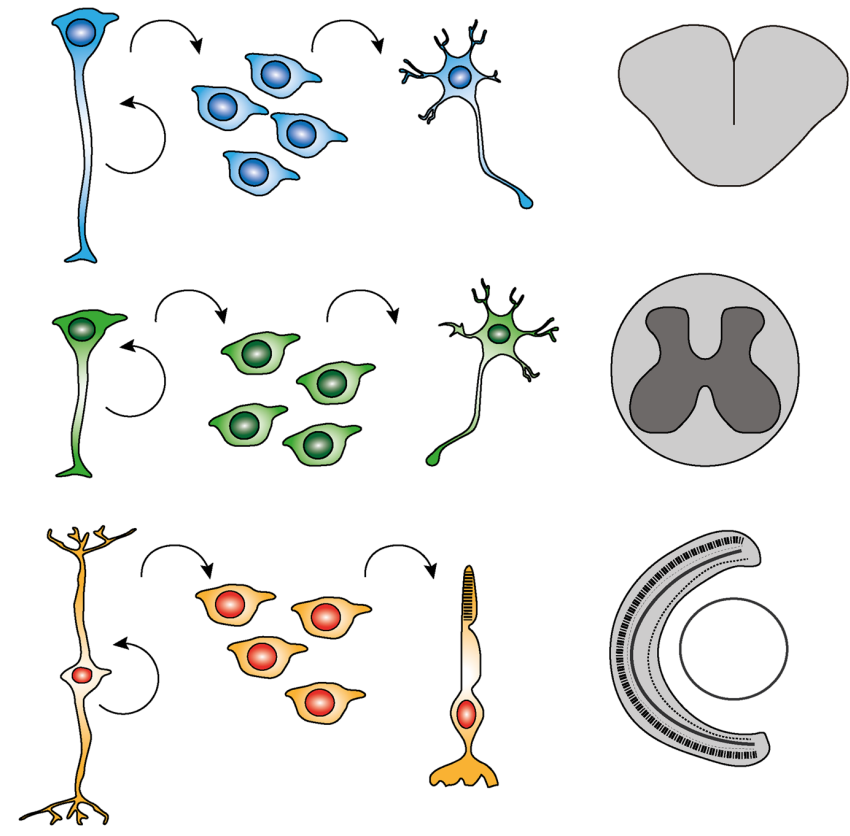

regeneration

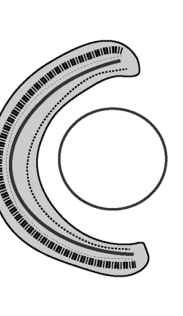

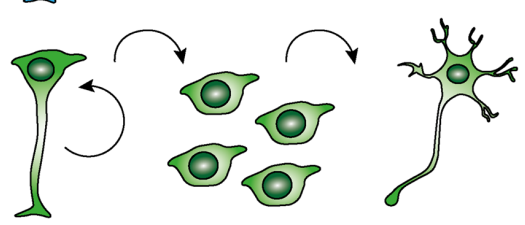

Fig. 2. Immunity related signals involved in the regenerative response in zebrafish CNS. Injury of the zebrafish central nervous system (telencephalon, spinal cord, retina) elicits a rapid and strong inflammatory response characterized by immune cell activation, proliferation and infiltration as well as secretion of inflammatory mediators (cytokines or lipid-derived factors). These are potent to stimulate and increase stem cell proliferation. In the zebrafish retina and telencephalon several inflammatory mediators have already been identified, whereas less is known about inflammatory regulators in the spinal cord after injury. Radial glial cells of the telencephalon are the source of newly generated neurons after injury, whereas in the spinal cord ependymal-radial glia contribute to regeneration of lostmotorneurons in response to damage. In the retina Müller glia cells are activated after lesion and proliferate to give rise to intermediate progenitors, which continue to proliferate and eventually differentiate to replenish lost photoreceptors. Abbreviations: IL, interleukin; TNF, tumor necrosis factor; CNTF, ciliary neurotrophic factor; $S D F, S D F$ - stromal cell-derived factor (also known as CXCL12); CCL, CC motif chemokine; $L T C_{4}$, leukotriene $C_{4} ;$ CysLT, cysteinyl leukotriene. 
Collectively, all these studies show that in organisms with high intrinsic regenerative potential of the central nervous system, inflammation is a very important part of the response. Increasing evidence further suggests that also in mammals certain aspects of the inflammatory response within the nervous system are important to allow tissue healing and restoration. In a naturally regenerating organism such as the zebrafish, the inflammatory response is required for successful regeneration. Immune cell activation, infiltration and secretion of inflammatory mediators stimulates central nervous system stem cells to proliferate and subsequently differentiate into cell types lost to injury (Fig. 2).

Despite great research efforts and increased understanding of regenerative mechanisms, many open questions are still remaining. We know about the general requirement of an inflammatory response in animals with great regenerative capacity, however, contribution of specific inflammatory mediators is still incompletely understood. Furthermore, the function of specialized immune cell subtypes needs to be evaluated in greater detail, with special focus on the specific spatio-temporal regulation of the inflammatory and regenerative response. With rapid progress being made in single cell sequencing, gene editing, live imaging technologies as well as drug screening methods, it is now possible to gain a more complete and detailed understanding of complex molecular and cellular events during regeneration, eventually allowing to target these in a specific manner also therapeutically.

Taken together, as the field moves towards a more differentiated view on neuro-inflammation after injury, future research should reveal the knowledge required for the design of novel immune-modulatory therapies to enhance central nervous system regeneration also in mammals.

\section{Acknowledgments}

The authors thank Stefan Hans and Veronika Kuscha for comments on an earlier version of this review, and members of the Brand lab for lively discussions. We are also grateful for grant support to our lab from the European Union (ERC-AdG-Zf-BrainReg), the Deutsche Forschungsgemeinschaft (BR 1746/6-1), and the German Excellence Initiative (CRTD seed grant).

\section{References}

AJAMIB, BENNETT JL, KRIEGER C, MCNAGNY KM, ROSSIFM V (2011). Infiltrating monocytes trigger EAE progression, but do not contribute to the resident microglia pool. Nat Neurosci 14: 1142-1149.

ALTMAN J, DAS GD (1965). Autoradiographic and histological evidence of postnatal hippocampal neurogenesis in rats. J Comp Neurol 124: 319-35.

ALUNNI A, BALLY-CUIF L (2016). A comparative view of regenerative neurogenesis in vertebrates. Development 143: 741-53.

AURORAAB, OLSON EN (2014). Immune Modulation of Stem Cells and Regeneration. Cell Stem Cell 15: 14-25.

AURORAAB, PORRELLO ER, TAN W, MAHMOUD AI, HILL J a., BASSEL-DUBY R, SADEK H a., OLSON EN (2014). Macrophages are required for neonatal heart regeneration. J Clin Invest 124: 1382-1392.

AYARI B, EL HACHIMI KH, YANICOSTAS C, LANDOULSI A, SOUSSI-YANICOSTAS $\mathrm{N}(2010)$. Prokineticin 2 expression is associated with neural repair of injured adult zebrafish telencephalon. J Neurotrauma 27: 959-972.

BALDWIN KT, CARBAJAL KS, SEGAL BM, GIGER RJ (2015). Neuroinflammation triggered by $\beta$-glucan/dectin-1 signaling enables CNS axon regeneration. Proc Natl Acad Sci USA 112: 2581-2586.

BARBOSA JS, SANCHEZ-GONZALEZ R, GIAIMO R Di, BAUMGART EV, THEIS FJ, NINKOVIC J, DI GIAIMO R, BAUMGART EV, THEIS FJ, GOTZ M, NINKOVIC J (2015). Live imaging of adult neural stem cell behavior in the intact and injured zebrafish brain. Science 348: 789-793.
BAUMGART EV, BARBOSA JS, BALLY-CUIF L, GÖTZ M, NINKOVIC J (2012). Stab wound injury of the zebrafish telencephalon: A model for comparative analysis of reactive gliosis. Glia 60: 343-357.

BAZAN, N.G. (2006). Arachidonic Acid Signalling in the Nervous System. In eLS, (Ed.). doi:10.1038/npg.els.0004045

BAZANNG (2001). COX-2 as a multifunctional neuronal modulator. NatMed7:414-415.

BAZAN NG (2014). Is There a Molecular Logic That Sustains Neuronal Functional Integrity and Survival? Lipid Signaling Is Necessary for Neuroprotective Neuronal Transcriptional Programs. Mol Neurobiol 50: 1-5.

BAZAN NG (2005b). Neuroprotectin D1 (NPD1): a DHA-derived mediator that protects brain and retina against cell injury-induced oxidative stress. Brain Pathol 15: 159-166.

BAZZONI F, TAMASSIA N, ROSSATO M, CASSATELLAM a. (2010). Understanding the molecular mechanisms of the multifaceted IL-10-mediated anti-inflammatory response: Lessons from neutrophils. Eur J Immunol 40: 2360-2368.

BECK BH, KIM HG, KIM H, SAMUEL S, LIU Z, SHRESTHA R, HAINES H, ZINN K, LOPEZ RD (2010). Adoptively transferred ex vivo expanded T cells mediate in vivo antitumor activity in preclinical mouse models of breast cancer. Breast Cancer Res Treat 122: 135-144.

BENNETTA ML, BENNETTA C, LIDDELOWA SA, AJAMI B, ZAMANIAN JL, FERNHOFF NB, MULINYAWE SB, BOHLEN CJ, ADIL A, TUCKER A, L.WEISSMAN I, CHANG EF, GORDON L, GRANT GA, HAYDEN GEPHART MG, BARRES BA (2016). New tools for studying microglia in the mouse and human CNS. Proc Natl Acad Sci USA 113: E1738-E1746.

BERG D a, KIRKHAM M, BELJAJEVA A, KNAPP D, HABERMANN B, RYGE J, TANAKAEM, SIMONA (2010). Efficient regeneration by activation of neurogenesis in homeostatically quiescent regions of the adult vertebrate brain. Development 137: 4127-4134.

BERNINGER B, JESSBERGER S (2016). Engineering of adult neurogenesis and gliogenesis. Cold Spring Harb Perspect Biol 8: 5.

BHATTARAI P, THOMAS AK, COSACAK MI, PAPADIMITRIOU C, MASHKARYAN V, FROC C, REINHARDT S, KURTH T, DAHL A, ZHANG Y, et al., (2016). IL4/ STAT6 Signaling Activates Neural Stem Cell Proliferation and Neurogenesis upon Amyloid-ß342 Aggregation in Adult Zebrafish Brain. Cell Rep 17: 941-948.

BLOCK ML, ZECCA L, HONG JS (2007). Microglia-mediated neurotoxicity: uncovering the molecular mechanisms. Nat Rev Neurosci 8: 57-69.

BUFFO A, RITE I, TRIPATHI P, LEPIER A, COLAK D, HORN A-P, MORI T, GÖTZ $M$ (2008). Origin and progeny of reactive gliosis: A source of multipotent cells in the injured brain. Proc Natl Acad Sci USA 105: 3581-3586.

BUFFO A, VOSKO MR, ERTÜRK D, HAMANN GF, JUCKER M, ROWITCH D, GÖTZ $M(2005)$. Expression pattern of the transcription factor Olig2 in response to brain injuries: implications for neuronal repair. ProcNat/Acad SciUSA 102: 18183-18188.

BUTOVSKY O, JEDRYCHOWSKI MP, MOORE CS, CIALIC R, LANSER AJ, GABRIELY G, KOEGLSPERGER T, DAKE B, WU PM, DOYKAN CE, FANEK Z, LIU L, CHEN Z, ROTHSTEIN JD, RANSOHOFF RM, GYGI SP, ANTEL JP, WEINER HL (2014). Identification of a unique TGF- $\beta$-dependent molecular and functional signature in microglia. Nat Neurosci 17: 131-143.

CÁMARA-LEMARROY CR, GUZMÁN-DE LAGARZAFJ, BARRERA-ORANDAYEA, CABELLO-GARCÍA AJ, GARCÍA-TAMEZ A, FERNÁNDEZ-GARZA NE (2008). Celecoxib accelerates functional recovery after sciatic nerve crush in the rat. $J$ Brachial Plex Peripher Nerve Inj 3: 25.

CAMERON H a, WOOLLEY CS, MCEWEN BS, GOULD E (1993). Differentiation of newly born neurons and glia in the dentate gyrus of the adult rat. Neuroscience 56: 337-344.

CERNAK I, O'CONNOR C, VINK R (2002). Inhibition of cyclooxygenase 2 by nimesulide improves cognitive outcome more than motor outcome following diffuse traumatic brain injury in rats. Exp Brain Res 147: 193-199.

CHEN AT, ZON LI (2009). Zebrafish blood stem cells. J Cell Biochem 108: 35-42.

COLTON CA (2009). Heterogeneity of microglial activation in the innate immune response in the brain. J Neuroimmune Pharmacol 4: 399-418

CORPS KN, ROTH TL, MCGAVERN DB (2015). Inflammation and Neuroprotection in Traumatic Brain Injury. JAMA Neurol 72: 355-362.

CORSER-JENSEN CE, GOODELL DJ, FREUND RK, SERBEDZIJA P, MURPHY RC, FARIAS SE, DELL'ACQUA ML, FREY LC, SERKOVA N, HEIDENREICH $\mathrm{K}$ a (2014). Blocking leukotriene synthesis attenuates the pathophysiology of traumatic brain injury and associated cognitive deficits. Exp Neurol 256: 7-16. 
CORTINA MS, HE J, RUSS T, BAZAN NG, BAZAN HEP (2013). Neuroprotectin D1 restores corneal nerve integrity and function after damage from experimental surgery. Investig Ophthalmol Vis Sci 54: 4109-4116.

DASH PK, MACH SA, MOOREAN (2000). Regional expression and role of cyclooxygenase-2 following experimental traumatic brain injury. J Neurotrauma 17:69-81.

DENNIS EA, NORRIS PC (2015). Eicosanoid storm in infection and inflammation. Nat Rev Immunol 15: 511-523.

DERECKI NC, CARDANI AN, YANG CH, QUINNIES KM, CRIHFIELD A, LYNCH KR, KIPNIS J (2010). Regulation of learning and memory by meningeal immunity: a key role for IL-4. J Exp Med 207: 1067-1080.

DEVRIES ME, KELVIN AA, XU L, RAN L, ROBINSON J, KELVIN DJ (2006). Defining the Origins and Evolution of the Chemokine/Chemokine Receptor System. J Immunol 176: 401-415.

DEY A, ALLEN J, HANKEY-GIBLIN PA (2015). Ontogeny and Polarization of Macrophages in Inflammation: Blood Monocytes Versus Tissue Macrophages. Front Immunol 5: 1-15.

DINKEL K, DHABHAR FS, SAPOLSKY RM (2004). Neurotoxic effects of polymorphonuclear granulocytes on hippocampal primary cultures. Proc Natl Acad Sci USA 101: 331-336.

DIOTEL N, VAILLANT C, GUEGUEN MM, MIRONOV S, ANGLADE I, SERVILI A, PELLEGRINI E, KAH O (2010). Cxcr4 and Cxcl12 expression in radial glial cells of the brain of adult zebrafish. J Comp Neurol 518: 4855-4876.

DOETSCHF,ALVAREZ-BUYLLAA(1996). Network of tangential pathways for neuronal migration in adult mammalian brain. Proc Natl Acad Sci USA 93: 14895-14900.

DYALLSC (2015). Long-chain omega-3 fatty acids and the brain: a review of the independent and shared effects of EPA, DPA and DHA. Front Aging Neurosci 7: 1-15.

EKDAHL CT, CLAASEN J-H, BONDE S, KOKAIA Z, LINDVALL O (2003). Inflammation is detrimental for neurogenesis in adult brain. Proc Natl Acad Sci USA 100: $13632-13637$

EKSTRÖM P, JOHNSSON C-M, OHLIN L-M (2001). Ventricular proliferation zones in the brain of an adult teleost fish and their relation to neuromeres and migration (secondary matrix) zones. J Comp Neurol 436: 92-110.

ELLWARDT E, WALSH JT, KIPNIS J, ZIPP F (2016). Understanding the Role of T Cells in CNS Homeostasis. Trends Immunol 37: 154-165.

ELSAEIDI F, BEMBEN MA, ZHAO X-F, GOLDMAN D (2014). Jak/Stat signaling stimulates zebrafish optic nerve regeneration and overcomes the inhibitory actions of Socs3 and Sfpq. J Neurosci 34: 2632-2644.

ERIKSSON P (1998). Neurogenesis in the adult human hippocampus. Nat Med 4: 1313-1317.

ERLANDSSON A, LIN C-HA, YU F, MORSHEAD CM (2011). Immunosuppression promotes endogenous neural stem and progenitor cell migration and tissue regeneration after ischemic injury. Exp Neurol 230: 48-57.

ERTA M, QUINTANA A, HIDALGO J (2012). Interleukin-6, a major cytokine in the central nervous system. Int J Biol Sci 8: 1254-1266.

FABEL K, WOLF SA, EHNINGER D, BABU H, LEAL-GALICIA P, KEMPERMANN $G$ (2009). Additive effects of physical exercise and environmental enrichment on adult hippocampal neurogenesis in mice. Front Neurosci 3: 50.

FARIASS, FREY LCL, MURPHYRC, HEIDENREICHKA(2009). Injury-related production of cysteinyl leukotrienes contributes to brain damage following experimental traumatic brain injury. J Neurotrauma 26: 1977-1986.

FAROOQUI AA, ONG WY, HORROCKS LA, FAROOQUI T (2000). Brain cytosolic phospholipase $\mathrm{A}(2)$ : Localization, role, and involvement in neurological diseases. Neuroscientist 6: 169-180.

FITCH MT, SILVER J (2008). CNS injury, glial scars, and inflammation: Inhibitory extracellular matrices and regeneration failure. Exp Neurol 209: 294-301.

FUNK CD (2001). Prostaglandins and leukotrienes: advances in eicosanoid biology. Science 294: 1871-1875

GABELS, KONCINAE, DORBANG, HEURTAUXT, BIRCKC, GLAABE, MICHELUCCI A, HEUSCHLING P, GRANDBARBE L (2015). Inflammation Promotes a Conversion of Astrocytes into Neural Progenitor Cells via NF-kB Activation. Mol Neurobiol. 53: 5041-55. doi: 10.1007/s12035-015-9428-3

GADANI SP, WALSH JT, LUKENS JR, KIPNIS J (2015). Dealing with Danger in the CNS: The Response of the Immune System to Injury. Neuron 87: 47-62.

GADIENTRa., OTTEN UH (1997). Interleukin-6 (IL-6) - Amolecule with both beneficial and destructive potentials. Prog Neurobiol 52: 379-390.
GALLINA D, ZELINKA C, FISCHERAJ (2014). Glucocorticoid receptors in the retina, Müller glia and the formation of Müller glia-derived progenitors. Development 3340-3351.

GANZ J, BRAND M (2016). Adult neurogenesis in fish. Cold Spring Harb Perspect Biol 8: a019018.

GARG SK, KIPNIS J, BANERJEE R (2009). IFN-y and IL-4 differentially shape metabolic responses and neuroprotective phenotype of astrocytes. J Neurochem 108: 1155-1166.

GARTHE A, ROEDER I, KEMPERMANN G (2016). Mice in an enriched environment learn more flexibly because of adult hippocampal neurogenesis. Hippocampus 26: $261-271$

GASCÓN S, MASSERDOTTI G, RUSSO GL, GÖTZ M (2017). Direct Neuronal Reprogramming: Achievements, Hurdles, and New Roads to Success. Cell Stem Cell 21: 18-34.

GAUTIER EL, SHAY T, MILLER J, GRETER M, JAKUBZICK C, IVANOV S, HELFT J, CHOW A, ELPEK KG, GORDONOV S, MAZLOOM AR, MA'AYAN A, CHUA W-J, HANSEN TH, TURLEY SJ, MERAD M, RANDOLPH GJ (2012). Gene-expression profiles and transcriptional regulatory pathways that underlie the identity and diversity of mouse tissue macrophages. Nat Immunol 13: 1118-1128.

GEMBERLING M, BAILEYTJ, HYDE DR, POSS KD (2013). The zebrafish as a model for complex tissue regeneration. Trends Genet 29: 611-620.

GEURTZEN K, VERNET A, FREIDIN A, RAUNER M, HOFBAUER LC, SCHNEIDER JE, BRAND M, KNOPF F (2017). Immune Suppressive and Bone Inhibitory Effects of Prednisolone in Growing and Regenerating Zebrafish Tissues. J Bone Miner Res. 32: 2476-2488.

GHASEMLOUN, BOUHYD, YANG J, LÓPEZ-VALESR, HABERM, THURAISINGAM T, HE G, RADZIOCH D, DING A, DAVID S (2010). Beneficial effects of secretory leukocyte protease inhibitor after spinal cord injury. Brain 133: 126-138.

GINHOUX F, GRETER M, LEBOEUF M, NANDI S, SEE P, GOKHAN S, MEHLER MF, CONWAY SJ, NG LG, STANLEY ER, SAMOKHVALOV IM, MERAD M (2010). Fate Mapping Analysis Reveals That Adult Microglia Derive from Primitive Macrophages. Science 330: 841-845.

GINHOUXF, JUNG S (2014). Monocytes and macrophages: developmental pathways and tissue homeostasis. Nat Rev Immunol 14: 392-404.

GOESSLING W, NORTH TE, LOEWER S, LORD AM, LEE S, STOICK-COOPER CL, WEIDINGER G, PUDER M, DALEY GQ, MOON RT, ZON LI (2009). Genetic Interaction of PGE2 and Wnt Signaling Regulates Developmental Specification of Stem Cells and Regeneration. Cell 136: 1136-1147.

GOLDSHMIT Y, SZTAL TE, JUSUF PR, HALL TE, NGUYEN-CHI M, CURRIE PD (2012). Fgf-Dependent Glial Cell Bridges Facilitate Spinal Cord Regeneration in Zebrafish. J Neurosci 32: 7477-7492.

GOPEZ JJ, YUE H, VASUDEVAN R, MALIK AS, FOGELSANGER LN, LEWIS S, PANIKASHVILI D, SHOHAMI E, JANSEN SA, NARAYAN RK, STRAUSS KI (2005). Cyclooxygenase-2-specific inhibitor improves functional outcomes, provides neuroprotection, and reduces inflammation in a rat model of traumatic brain injury. Neurosurgery 56: 590-604.

GRABERT K, MICHOEL T, KARAVOLOS MH, CLOHISEY S, BAILLIE JK, STEVENS MP, FREEMAN TC, SUMMERS KM, MCCOLL BW (2016). Microglia brain region-dependent diversity and selective regional sensitivities to aging. Nat Neurosci 19: 504-516.

GRANDELH, BRAND M (2013). Comparative aspects of adult neural stem cell activity in vertebrates. Dev Genes Evol 223: 131-147.

GRANDEL H, KASLIN J, GANZ J, WENZEL I, BRAND M (2006). Neural stem cells and neurogenesis in the adult zebrafish brain: origin, proliferation dynamics, migration and cell fate. Dev Biol 295: 263-277.

GROSSER T, YUSUFF S, CHESKIS E, PACK M a, FITZGERALD G a (2002). Developmental expression of functional cyclooxygenases in zebrafish. Proc Natl Acad Sci USA 99: 8418-8423.

GRUOL DL (2015). IL-6 regulation of synaptic function in the CNS. Neuropharmacol 96: 42-54.

VAN HAM TJ, BRADY $C$ a, KALICHARAN RD, OOSTERHOF N, KUIPERS J, VEENSTRA-ALGRA A, SJOLLEMA $\mathrm{K}$ a, PETERSON RT, KAMPINGA HH, GIEPMANS BNG (2014). Intravital correlated microscopy reveals differential macrophage and microglial dynamics during resolution of neuroinflammation. Dis Model Mech 7: 857-869.

HAMMOND ME, LAPOINTE GR, FEUCHT PH, HILT S, GALLEGOS CA, GORDON 
CA, GIEDLIN MA, MULLENBACH G, TEKAMP-OLSON P (1995). IL-8 induces neutrophil chemotaxis predominantly via type I IL-8 receptors. J Immunol 155: 1428-1433.

HAMON A, ROGER JE, YANG XJ, PERRON M (2016). Mueller glial cell-dependent regeneration of the neural retina: An overview across vertebrate model systems. Dev Dyn 245: 727-738.

HICKMAN SE, KINGERY ND, OHSUMI TK, BOROWSKY ML, WANG L, MEANS TK, EL KHOURY J (2013). The microglial sensome revealed by direct RNA sequencing. Nat Neurosci 16: 1896-905.

HOWE CL, URED, ADELSON JD, LAFRANCE-COREYR, JOHNSONA, RODRIGUEZ $M$ (2007). CD8 + T cells directed against a viral peptide contribute to loss of motor function by disrupting axonal transport in a viral model of fulminant demyelination. J Neuroimmunol 188: 13-21.

HU X, LEAK RK, SHI Y, SUENAGA J, GAO Y, ZHENG P, CHEN J (2014). Microglial and macrophage polarization-new prospects for brain repair. Nat Rev Neurol 11: 56-64.

HUANG WC, YANG CC, CHEN IH, LIU YML, CHANG SJ, CHUANG YJ (2013). Treatment of Glucocorticoids Inhibited Early Immune Responses and Impaired Cardiac Repair in Adult Zebrafish. PLoS One 8: 1-11.

HUBER C, MARSCHALLINGERJ, TEMPFER H, COUILLARD-DESPRES S, BAUER H, RIVERAJ, AIGNERL (2011). Inhibition of Leukotriene Receptors Boosts Neural Progenitor Proliferation. Cell Physiol Biochem. 28:793-804. doi:10.1159/000335793

HURLEY SD, OLSCHOWKA JA, O'BANION MK (2002). Cyclooxygenase Inhibition as a Strategy to Ameliorate Brain Injury. $J$ Neurotrauma 19: 1-15.

IMITOLA J, RADDASSI K, PARK KI, MUELLER F-J, NIETO M, TENG YD, FRENKEL D, LI J, SIDMAN RL, WALSH CA, SNYDER EY, KHOURY SJ (2004). Directed migration of neural stem cells to sites of CNS injury by the stromal cell-derived factor 1alpha/CXC chemokine receptor 4 pathway. Proc Natl Acad Sci USA 101: 18117-18122.

IOSIF RE, EKDAHL CT, AHLENIUS H, PRONK CJH, BONDE S, KOKAIA Z, JACOBSEN S-EW, LINDVALL O (2006). Tumor Necrosis Factor Receptor 1 Is a Negative Regulator of Progenitor Proliferation in Adult Hippocampal Neurogenesis. J Neurosci 26: 9703-9712.

ISHIKAWA TO, GRIFFIN KJP, BANERJEE U, HERSCHMAN HR (2007). The zebrafish genome contains two inducible, functional cyclooxygenase-2 genes. Biochem Biophys Res Commun 352: 181-187.

JABLONSKI KA, AMICI SA, WEBB LM, RUIZ-ROSADO JDD, POPOVICH PG, PARTIDA-SANCHEZ S, GUERAU-DE-ARELLANO M (2015). Novel markers to delineate murine M1 and M2 macrophages. PLoS One 10: 5-11.

JESSBERGERS, KEMPERMANN G (2003). Adult-born hippocampal neurons mature into activity-dependent responsiveness. Eur J Neurosci 18: 2707-2712.

KASLIN J, GANZJ, BRAND M (2008). Proliferation, neurogenesis and regeneration in the non-mammalian vertebrate brain. Philos Trans R Soc B Biol Sci363: 101-122.

KASLIN J, KROEHNE V, GANZ J, HANS S, BRAND M (2017). Distinct roles of neuroepithelial-like and radial glia-like progenitor cells in cerebellar regeneration. Development 144: 1462-1471.

KEIGHTLEY MC, WANG CH, PAZHAKH V, LIESCHKE GJ (2014). Delineating the roles of neutrophils and macrophages in zebrafish regeneration models. Int $J$ Biochem Cell Biol 56: 92-106.

KEMPERMANN G (2016). Adult neurogenesis: An evolutionary perspective. Cold Spring Harb Perspect Biol 8: 2.

KEMPERMANN G (2012). New neurons for "survival of the fittest." Nat Rev Neurosci 13: 727-736.

KEMPERMANN G, KUHN HG, GAGE FH (1997). More hippocampal neurons in adult mice living in an enriched environment. Nature 386: 493-495.

KENNE E, ERLANDSSON A, LINDBOM L, HILLERED L, CLAUSEN F (2012). Neutrophil depletion reduces edema formation and tissue loss following traumatic brain injury in mice. J Neuroinflammation 9: 17.

KERSCHENSTEINER M, GALLMEIER E, BEHRENS L, LEAL V, MISGELD T, KLINKERT WE, KOLBECK R, HOPPE E, OROPEZA-WEKERLE RL, BARTKE I, STADELMANN C, LASSMANN H, WEKERLE H, HOHLFELD R (1999). Activated human T cells, $B$ cells, and monocytes produce brain-derived neurotrophic factor in vitro and in inflammatory brain lesions: a neuroprotective role of inflammation? J Exp Med 189: 865-870.

KETTENMANN H, HANISCH U-K, NODA M, VERKHRATSKY A (2011). Physiology of microglia. Physiol Rev 91: 461-553.
KIGERL KA, GENSEL JC, ANKENY DP, ALEXANDER JK, DONNELLY DJ, POPOVICH PG (2009). Identification of two distinct macrophage subsets with divergent effects causing either neurotoxicity or regeneration in the injured mouse spinal cord. J Neurosci 29: 13435-13444.

KIM CC, NAKAMURA MC, HSIEH CL (2016). Brain trauma elicits non-canonical macrophage activation states. J Neuroinflammation 13: 117.

KIRKHAM M, BERG D a., SIMON A (2011). Microglia activation during neuroregeneration in the adult vertebrate brain. Neurosci Lett 497: 11-16.

KISHIMOTO N, SHIMIZU K, SAWAMOTO K (2012). Neuronal regeneration in a zebrafish model of adult brain injury. Dis Model Mech 5: 200-209.

KIZIL C, DUDCZIG S, KYRITSIS N, MACHATE A, BLAESCHE J, KROEHNE V, BRAND M (2012). The chemokine receptor cxcr5 regulates the regenerative neurogenesis response in the adult zebrafish brain. Neural Dev 7: 27.

KIZIL C, KASLIN J, KROEHNE V, BRAND M (2011). Adult neurogenesis and brain regeneration in zebrafish. Dev Neurobiol 72: 429-461.

KNOBLACH SM, FADEN Al (1998). Interleukin-10 improves outcome and alters proinflammatory cytokine expression after experimental traumatic brain injury. Exp Neurol 153: 143-151.

KOSSMANN T, STAHEL PF, LENZLINGER PM, REDL H, DUBS RW, TRENTZ O, SCHLAG G, MORGANTI-KOSSMANN MC (1997). Interleukin-8 released into the cerebrospinal fluid after brain injury is associated with blood-brain barrier dysfunction and nerve growth factor production. J Cereb Blood Flow Metab 17: 280-289.

KROEHNE V, FREUDENREICH D, HANS S, KASLIN J, BRAND M (2011). Regeneration of the adult zebrafish brain from neurogenic radial glia-type progenitors. Development 138: 4831-4841.

KRONENBERG G, REUTER K, STEINER B, BRANDT MD, JESSBERGER S, YAMAGUCHI M, KEMPERMANN G (2003). Subpopulations of proliferating cells of the adult hippocampus respond differently to physiologic neurogenic stimuli. $J$ Comp Neurol 467: 455-463.

KUHN HG, DICKINSON-ANSON H, GAGE FH (1996). Neurogenesis in the dentate gyrus of the adult rat: age-related decrease of neuronal progenitor proliferation. J Neurosci 16: 2027-2033.

KURIMOTO T, YIN Y, HABBOUB G, GILBERT H-Y, LI Y, NAKAO S, HAFEZI-MOGHADAM A, BENOWITZ LI (2013). Neutrophils Express Oncomodulin and Promote Optic Nerve Regeneration. J Neurosci 33: 14816-14824.

KUSCHA V, BARREIRO-IGLESIAS A, BECKER CG, BECKER T (2012). Plasticity of tyrosine hydroxylase and serotonergic systems in the regenerating spinal cord of adult zebrafish. J Comp Neurol 520: 933-951.

KUSCHA V, FRAZER SL, DIAS TB, HIBI M, BECKERT, BECKER CG (2012). Lesioninduced generation of interneuron cell types in specific dorsoventral domains in the spinal cord of adult zebrafish. J Comp Neurol 520: 3604-3616.

KWON MJ, KIM J, SHIN H, JEONG SR, KANG YM, CHOI JY, HWANG DH, KIM BG (2013). Contribution of Macrophages to Enhanced Regenerative Capacity of Dorsal Root Ganglia Sensory Neurons by Conditioning Injury. J Neurosci 33: 15095-15108.

KWON MJ, YOON HJ, KIM BG (2016). Regeneration-associated macrophages: A novel approach to boost intrinsic regenerative capacity for axon regeneration. Neural Regen Res 11: 1368-1371.

KYRITSIS N, KIZIL C, ZOCHER S, KROEHNE V, KASLIN J, FREUDENREICH D, ILTZSCHE A, BRAND M (2012). Acute inflammation initiates the regenerative response in the adult zebrafish brain. Science 338: 1353-1356.

LANGENAU DM, FERRANDO A a, TRAVER D, KUTOK JL, HEZEL J-PD, KANKI JP, ZON LI, LOOK a T, TREDE NS (2004). In vivo tracking of T cell development, ablation, and engraftment in transgenic zebrafish. Proc Natl Acad Sci USA 101: 7369-7374.

LANGENAU DM, ZON LI (2005). The zebrafish: a new model of T-cell and thymic development. Nat Rev Immunol 5: 307-317.

LEIBINGERM, MÜLLERa, GOBRECHTP, DIEKMANN H, ANDREADAKIa, FISCHER D (2013). Interleukin-6 contributes to CNS axon regeneration upon inflammatory stimulation. Cell Death Dis 4: e609.

LEITER O, KEMPERMANN G, WALKER TL (2016). A Common Language: How neuroimmunological cross talk regulates adult hippocampal neurogenesis. Stem Cells Int 2016: 1681590.

LENKOWSKI JR, QIN Z, SIFUENTES CJ, THUMMEL R, SOTO CM, MOENS CB, RAYMOND PA (2013). Retinal regeneration in adult zebrafish requires regulation of TGFb signaling. Glia 61: 1687-1697. 
LENKOWSKI JR, RAYMOND PA (2014). Mueller glia: Stem cells for generation and regeneration of retinal neurons in teleost fish. Prog Retin Eye Res 40: 94-123.

LIBERTO CM, ALBRECHT PJ, HERX LM, YONG VW, LEVISON SW (2004). Pro-regenerative properties of cytokine-activated astrocytes. J Neurochem 89: 1092-1100.

LIESCHKE GJ, OATES a C, CROWHURST MO, WARD a C, LAYTON JE (2001). Morphologic and functional characterization of granulocytes and macrophages in embryonic and adult zebrafish. Blood 98: 3087-3096.

LINDSEY BW, TROPEPE V (2006). A comparative framework for understanding the biological principles of adult neurogenesis. Prog Neurobiol 80: 281-307.

LINDVALL O, KOKAIA Z (2015). Neurogenesis following stroke affecting the adult brain. Cold Spring Harb Perspect Biol 7: 1-20.

LLORENS-BOBADILLA E, ZHAO S, BASER A, SAIZ-CASTRO G, ZWADLO K, MARTIN-VILLALBA A (2015). Single-Cell Transcriptomics Reveals a Population of Dormant Neural Stem Cells that Become Activated upon Brain Injury. Cell Stem Cell 17: 1-12.

LONDON A, COHEN M, SCHWARTZ M (2013). Microglia and monocyte-derived macrophages: functionally distinct populations that act in concert in CNS plasticity and repair. Front Cell Neurosci 7: 34.

LUO C-LL, LI Q-QQ, CHEN X-PP, ZHANG X-MM, LI L-LL, LI B-XX, ZHAO Z-QQ, TAO L-YY (2013). Lipoxin A4 attenuates brain damage and downregulates the production of pro-inflammatory cytokines and phosphorylated mitogen-activated protein kinases in a mouse model of traumatic brain injury. Brain Res 1502: 1-10.

MARCHESELLI VL, HONG S, LUKIW WJ, TIAN XH, GRONERT K, MUSTO A, HARDY M, GIMENEZ JM, CHIANG N, SERHAN CN, BAZAN NG (2003). Novel Docosanoids Inhibit Brain Ischemia-Reperfusion-mediated Leukocyte Infiltration and Pro-inflammatory Gene Expression. J Biol Chem 278: 43807-43817.

MARSCHALLINGER J, SCHÄFFNER I, KLEIN B, GELFERT R, RIVERA FJ, ILLES S, GRASSNER L, JANSSEN M, ROTHENEICHNER P, SCHMUCKERMAIR C, et al., (2015). Structural and functional rejuvenation of the aged brain by an approved anti-asthmatic drug. Nat Commun 6: 8466.

MÄRZ M, SCHMIDT R, RASTEGAR S, STRÄHLE U (2011). Regenerative response following stab injury in the adultzebrafish telencephalon. Dev Dyn240:2221-2231.

MATHIAS JR, PERRIN BJ, LIU T-X, KANKI J, LOOK a T, HUTTENLOCHERA (2006). Resolution of inflammation by retrograde chemotaxis of neutrophils in transgenic zebrafish. J Leukoc Biol 80: 1281-1288.

MATHIEU P, BATTISTA D, DEPINO A, ROCA V, GRACIARENA M, PITOSSI F (2010). The more you have, the less you get: the functional role of inflammation on neuronal differentiation of endogenous and transplanted neural stem cells in the adult brain. $J$ Neurochem 112: 1368-1385.

MAZAHERI F, BREUS O, DURDU S, HAAS P, WITTBRODT J, GILMOUR D, PERI $F$ (2014). Distinct roles for BAl1 and TIM-4 in the engulfment of dying neurons by microglia. Nat Commun 5: 4046 .

MCCOY MK, TANSEY MG (2008). TNF signaling inhibition in the CNS: implications for normal brain function and neurodegenerative disease. J Neuroinflammation 5: 45 .

MCKEE CA, LUKENS JR (2016). Emerging Roles for the Immune System in Traumatic Brain Injury. Front Immunol 7: 1-17.

MEIRELES AM, SHIAU CE, GUENTHER C a, SIDIK H, KINGSLEY DM, TALBOT WS (2014). The Phosphate Exporter xpr1b Is Required for Differentiation of TissueResident Macrophages. Cell Rep 8: 1659-1667.

MIRON VE, BOYD A, ZHAO J-W, YUEN TJ, RUCKH JM, SHADRACH JL, VAN WIJNGAARDEN P, WAGERS AJ, WILLIAMS A, FRANKLIN RJM, FFRENCHCONSTANT C (2013). M2 microglia and macrophages drive oligodendrocyte differentiation during CNS remyelination. Nat Neurosci 16: 1211-1218.

MOALEM G, MONSONEGO A, SHANI Y, COHEN IR, SCHWARTZ M (1999). Differential $T$ cell response in central and peripheral nerve injury: connection with immune privilege. FASEB J 13: 1207-1217.

MONJE ML, TODA H, PALMER TD (2003). Inflammatory blockade restores adult hippocampal neurogenesis. Science 302: 1760-1765.

MOORE JC, MULLIGAN TS, TORRES YORDÁN N, CASTRANOVA D, PHAM VN, TANG Q, LOBBARDI R, ANSELMO A, LIWSKI RS, BERMAN JN, SADREYEV RI, WEINSTEIN BM, LANGENAU DM (2016). T cell immune deficiency in zap70 mutant zebrafish. Mol Cell Biol: MCB.00281-16.

MORITZ C, BERARDI F, ABATE C, PERI F (2015). Live imaging reveals a new role for the sigma-1 ( $\sigma 1)$ receptor in allowing microglia to leave brain injuries. Neurosci Lett 591: 2-7.
MOSSER DM, EDWARDS JP (2008). Exploring the full spectrum of macrophage activation. Nat Rev Immunol 8: 958-969.

MURRAY PJ (2005). The primary mechanism of the IL-10-regulated antiinflammatory response is to selectively inhibit transcription. Proc Natl Acad Sci USA 102: 8686-8691.

MURRAY PJ, ALLEN JE, BISWAS SK, FISHER EA, GILROY DW, GOERDT S, GORDON S, HAMILTON JA, IVASHKIV LB, LAWRENCE T, et al., (2014). Macrophage Activation and Polarization: Nomenclature and Experimental Guidelines. Immunity 41: 14-20.

MUSSACK T, BIBERTHALER P, KANZ K, WIEDEMANN E, GIPPNER-STEPPERT C, MUTSCHLER W, JOCHUM M (2002). Serum S-100B and interleukin-8 as predictive markers for comparative neurologic outcome analysis of patients after cardiac arrest and severe traumatic brain injury. Crit Care Med 30: 2669-2674.

NAGASHIMA M, BARTHEL LK, RAYMOND PA (2013). A self-renewing division of zebrafish Müller glial cells generates neuronal progenitors that require $\mathrm{N}$-cadherin to regenerate retinal neurons. Development 140: 4510-4521.

NEIRINCKXV, COSTE C, FRANZENR, GOTHOTA, ROGISTERB, WISLETS (2014) Neutrophil contribution to spinal cord injury and repair. J Neuroinflammation 11:150.

NELMS K, KEEGAN a D, ZAMORANOJ, RYAN JJ, PAULWE (1999). The IL-4 receptor: signaling mechanisms and biologic functions. Annu Rev Immunol 17: 701-738.

NELSON CM, ACKERMAN KM, O'HAYER P, BAILEY TJ, GORSUCH RA, HYDE DR (2013). Tumor Necrosis Factor-Alpha Is Produced by Dying Retinal Neurons and Is Required for Muller Glia Proliferation during Zebrafish Retinal Regeneration. J Neurosci 33: 6524-6539.

NGUYEN-CHI M, LAPLACE-BUILHE B, TRAVNICKOVAJ, LUZ-CRAWFORDP,TEJEDOR G, PHAN QT, DUROUX-RICHARD I, LEVRAUD J-P, KISSA K, LUTFALLA G, JORGENSEN C, DJOUAD F (2015). Identification of polarized macrophage subsets in zebrafish. eLife 4: 1-14.

NIEMI JP, DEFRANCESCO-LISOWITZA, CREGG JM, HOWARTH M, ZIGMOND RE (2016). Overexpression of the monocyte chemokine CCL2 in dorsal root ganglion neurons causes a conditioning-like increase in neurite outgrowth and does so via a STAT3 dependent mechanism. Exp Neurol 275: 25-37.

NORTH TE, GOESSLING W, WALKLEY CR, LENGERKE C, KOPANI KR, LORD AM, WEBER GJ, BOWMAN T V, JANG I-H, GROSSER T, FITZGERALD G a, DALEY GQ, ORKIN SH, ZON LI (2007). Prostaglandin E2 regulates vertebrate haematopoietic stem cell homeostasis. Nature 447: 1007-1011.

OEHLERS SHB, FLORES MV, HALL CJ, O'TOOLE R, SWIFT S, CROSIER KE, CROSIER PS (2010). Expression of zebrafish cxcl8 (interleukin-8) and its receptors during development and in response to immune stimulation. Dev Comp Immunol 34: 352-359.

OHNMACHT J, YANG Y, MAURER GW, BARREIRO-IGLESIAS A, TSAROUCHAS TM, WEHNER D, SIEGER D, BECKER CG, BECKER T (2016). Spinal motor neurons are regenerated after mechanical lesion and genetic ablation in larval zebrafish. Development 143: 1464-1474.

DE OLIVEIRA S, REYES-ALDASORO CC, CANDEL S, RENSHAW S a, MULERO V, CALADO A (2013). Cxcl8 (IL-8) mediates neutrophil recruitment and behavior in the zebrafish inflammatory response. J Immunol 190: 4349-4359.

DEOLIVEIRAS, ROSOWSKIEE, HUTTENLOCHERA(2016). Neutrophil migration in infection and wound repair: going forward in reverse. Nat Rev Immunol 16:378-391.

PAIK EJ, ZON LI (2010). Hematopoietic development in the zebrafish. Int J Dev Biol 54: 1127-1137.

PARISH CL, BELJAJEVA A, ARENAS E, SIMON A (2007). Midbrain dopaminergic neurogenesis and behavioural recovery in a salamander lesion-induced regeneration model. Development 134: 2881-2887.

PERDIGUERO EG, GEISSMANN F (2015). The development and maintenance of resident macrophages. Nat Immunol 17: 2-8.

PEREZ-ASENSIO FJ, PERPIÑÁ U, PLANAS AM, POZAS E (2013). Interleukin-10 regulates progenitor differentiation and modulates neurogenesis in adult brain. J Cell Sci 126: 4208-4219.

PÉRON S, BERNINGER B (2015). Reawakening the sleeping beauty in the adult brain: Neurogenesis from parenchymal glia. Curr Opin Genet Dev 34: 46-53.

PETRIE T, STRAND N, TSUNG-YANG C, RABINOWITZ JS, MOON RT (2014). Macrophages modulate adult zebrafish tail fin regeneration. Development 141: 2581-2591.

PHILLIS JW, HORROCKS LA, FAROOQUI AA (2006). Cyclooxygenases, lipoxygenases, and epoxygenases in CNS: Their role and involvement in neurological 
disorders. Brain Res Rev 52: 201-243.

PONOMAREV ED, MARESZK, TANY, DITTELBN (2007). CNS-derived interleukin-4 is essential for the regulation of autoimmune inflammation and induces a state of alternative activation in microglial cells. $J$ Neurosci 27: 10714-10721.

POPOVICH PG, STOKES BT, WHITACRE CC (1996). Concept of autoimmunity following spinal cord injury: Possible roles for T lymphocytes in the traumatized central nervous system. J Neurosci Res 45: 349-363.

POPOVICH PG, WEI P, STOKES BT (1997). Cellular inflammatory response after spinal cord injury in Sprague-Dawley and Lewis rats. J Comp Neuro/377:443-464.

VANPRAAGH, KEMPERMANN G, GAGEFH (1999). Running increases cell proliferation and neurogenesis in the adult mouse dentate gyrus. Nat Neurosci2: 266-270.

PRINS M, GRECO T, ALEXANDER D, GIZA CC (2013). The pathophysiology of traumatic brain injury at a glance. Dis Model Mech 6: 1307-1315.

PRINZ M, PRILLER J (2014). Microglia and brain macrophages in the molecular age: from origin to neuropsychiatric disease. Nat Rev Neurosci 15: 300-312.

PROBERT L (2015). TNF and its receptors in the CNS: The essential, the desirable and the deleterious effects. Neuroscience 302: 2-22.

RAKIC P (1985). Limits of Neurogenesis in Primates. Science 227: 1054-1055.

RAPOSO C, SCHWARTZM (2014). Glial scar and immune cell involvement in tissue remodeling and repair following acute CNS injuries. Glia 62: 1895-1904.

RAYMOND PA, BARTHELLK, BERNARDOS RL, PERKOWSKI JJ (2006). Molecular characterization of retinal stem cells and their niches in adult zebrafish. $B M C$ Dev Biol 6: 36.

REIMER MM, SORENSEN I, KUSCHA V, FRANK RE, LIU C, BECKER CG, BECKER $T(2008)$. Motor neuron regeneration in adult zebrafish. J Neurosci28: 8510-8516.

RENSHAW S a., TREDE NS (2012). A model 450 million years in the making: zebrafish and vertebrate immunity. Dis Model Mech 5: 38-47.

RICCIOTTIE, FITZGERALD GA (2011). Prostaglandins and inflammation. Arterioscler Thromb Vasc Biol 31: 986-1000.

ROSENBERGAF, WOLMAN MA, FRANZINI-ARMSTRONG C, GRANATO M (2012). In vivo Nerve - Macrophage Interactions Following Peripheral Nerve Injury. In vivo (Brooklyn) 32: 3898-3909.

ROSSI F, CASANO AM, HENKE K, RICHTER K, PERI F (2015). The SLC7A7 Transporter Identifies Microglial Precursors prior to Entry into the Brain. Cell Rep: 1-10.

ROUZER CA, MARNETT LJ (2008). Cyclooxygenases: structural and functional insights. J Lipid Res 50: S29-S34.

SATOH J IChi, KINO Y, ASAHINA N, TAKITANI M, MIYOSHI J, ISHIDA T, SAITO Y (2016). TMEM119 marks a subset of microglia in the human brain. Neuropathology 36: 39-49.

SAVAN R, SAKAI M (2005). Genomics of fish cytokines. Comp Biochem Physiol- Part D Genomics Proteomics 1: 89-101.

SCHELLER J, CHALARIS A, SCHMIDT-ARRAS D, ROSE-JOHN S (2011). The proand anti-inflammatory properties of the cytokine interleukin-6. Biochim Biophys Acta - Mol Cell Res 1813: 878-888.

SCHWARTZ M, BARUCH K (2014). The resolution of neuroinflammation in neurodegeneration: Leukocyte recruitment via the choroid plexus. EMBO J 33: 7-20.

SERHAN CN, CHIANG N, VAN DYKE TE (2008). Resolving inflammation: dual antiinflammatory and pro-resolution lipid mediators. Nat Rev Immunol 8: 349-361.

SHECHTER R, LONDON A, VAROL C, RAPOSO C, CUSIMANO M, YOVEL G, ROLLSA, MACKM, PLUCHINO S, MARTINO G, JUNG S, SCHWARTZM (2009). Infiltrating blood-derived macrophages are vital cells playing an anti-inflammatory role in recovery from spinal cord injury in mice. PLoS Med 6: e1000113.

SHECHTER R, MILLER O, YOVEL G, ROSENZWEIG N, LONDON A, RUCKH J, KIM KW, KLEIN E, KALCHENKO V, BENDEL P, LIRA SA, JUNG S, SCHWARTZ M (2013). Recruitment of Beneficial M2 Macrophages to Injured Spinal Cord Is Orchestrated by Remote Brain Choroid Plexus. Immunity 38: 555-569.

SHINOMIYA S, NARABA H, UENO a, UTSUNOMIYA I, MARUYAMA T, OHUCHIDA $S$, USHIKUBI F, YUKI K, NARUMIYA S, SUGIMOTO Y, ICHIKAWA a, OH-ISHI S (2001). Regulation of TNFalpha and interleukin-10 production by prostaglandins I(2) and $\mathrm{E}(2)$ : studies with prostaglandin receptor-deficient mice and prostaglandin $\mathrm{E}$ receptor subtype-selective synthetic agonists. Biochem Pharmaco/61:1153-1160.

SHRESTHA R, MILLINGTON O, BREWER J, DEV KK, BUSHELL TJ (2014). Lymphocyte-mediated neuroprotection in in vitro models of excitotoxicity involves astrocytic activation and the inhibition of MAP kinase signalling pathways. Neu- ropharmacology 76: 184-193.

SIEGERD, MORITZC, ZIEGENHALST, PRYKHOZHIJ S, PERIF (2012). Long-Range Ca2+ Waves Transmit Brain-Damage Signals to Microglia. Dev Cell22: 1138-1148.

SIFUENTES CJ, KIM JW, SWAROOP A, RAYMOND PA (2016). Rapid, dynamic activation of Mueller Glial stem cell responses in Zebrafish. Investig Ophthalmol Vis Sci 57: 5148-5160.

SOFRONIEW M V. (2009). Molecular dissection of reactive astrogliosis and glial scar formation. Trends Neurosci 32: 638-647.

SPALDING KL, BERGMANNO, ALKASS K, BERNARD S, SALEHPOURM, HUTTNER HB, BOSTROM E, WESTERLUND I, VIAL C, BUCHHOLZ B a, POSSNERT G, MASH DC, DRUID H, FRISEN J (2013). Dynamics of hippocampal neurogenesis in adult humans. Cell 153: 1219-1227.

STARNES TW, HUTTENLOCHER A (2012). Neutrophil reverse migration becomes transparent with zebrafish. Adv Hematol 2012: 398640

STIRLING DP, LIUS, KUBESP, YONG VW (2009). Depletion of Ly6G/Gr-1 leukocytes after spinal cord injury in mice alters wound healing and worsens neurological outcome. J Neurosci 29: 753-764.

STIRLING DP, YONG VW (2008). Dynamics of the inflammatory response after murine spinal cord injury revealed by flow cytometry. J Neurosci Res 86: 1944-1958.

STOUT RD (2010). Editorial: macrophage functional phenotypes: no alternatives in dermal wound healing? J Leukoc Biol 87: 19-21.

TAGA T, KISHIMOTO T (1997). gp130 AND THE INTERLEUKIN-6 FAMILY OF CYTOKINES. Annu Rev Immunol 15: 797-819.

TANAKA EM, FERRETTI P (2009). Considering the evolution of regeneration in the central nervous system. Nat Rev Neurosci 10: 713-723.

TANG Y, LE W (2016). Differential Roles of M1 and M2 Microglia in Neurodegenerative Diseases. Mol Neurobiol 53: 1181-1194.

TAPPEINER C, MAURER E, SALLIN P, BISE T, ENZMANN V, TSCHOPP M (2016). Inhibition of the TGF $\beta$ Pathway Enhances Retinal Regeneration in Adult Zebrafish. PLoS One 11: e0167073.

TAUZIN S, STARNES TW, BECKER FB, LAM P -y., HUTTENLOCHER a. (2014). Redox and Src family kinase signaling control leukocyte wound attraction and neutrophil reverse migration. J Cell Biol 207: 589-598.

THAN-TRONG E, BALLY-CUIF L (2015). Radial glia and neural progenitors in the adult zebrafish central nervous system. Glia 63: 1406-1428.

VILLEDA SA, LUO J, MOSHER KI, ZOU B, BRITSCHGI M, BIERI G, STAN TM, FAINBERG N, DING Z, EGGEL A, et al., (2011). The ageing systemic milieu negatively regulates neurogenesis and cognitive function. Nature 477: 90-94.

WAJANT H, PFIZENMAIER K, SCHEURICH P (2003). Tumor necrosis factor signaling. Cell Death Differ 10: 45-65.

WALSH JT, WATSON N, KIPNIS J (2014). T cells in the central nervous system: Messengers of destruction or purveyors of protection? Immunology 141:340-344.

WAN J, GOLDMAN D (2016). Retina regeneration in zebrafish. Curr Opin Genet Dev 40: 41-47.

WANG X, FU S, WANG Y, YU P, HU J, GU W, XU XM, LU P (2007). Interleukin-1 beta mediates proliferation and differentiation of multipotent neural precursor cells through the activation of SAPK/JNK pathway. Mol Cell Neurosci 36: 343-354.

WOLF S a, STEINER B, WENGNERA, LIPP M, KAMMERTOENS T, KEMPERMANN $G$ (2009). Adaptive peripheral immune response increases proliferation of neural precursor cells in the adult hippocampus. FASEB J 23: 3121-3128.

XIONG X, BARRETO GE, XUL, OUYANG YB, XIEX, GIFFARD RG (2011). Increased brain injury and worsened neurological outcome in interleukin-4 knockout mice after transient focal cerebral ischemia. Stroke 42: 2026-2032.

XIONG Y, MAHMOOD A, CHOPP M (2013). Animal models of traumatic brain injury. Nat Rev Neurosci 14: 128-142.

XU J, ZHU L, HE S, WU Y, JIN W, YU T, QU JY, WEN Z (2015). Temporal-Spatial Resolution Fate Mapping Reveals Distinct Origins for Embryonic and Adult Microglia in Zebrafish. Dev Cell 34: 632-641.

YANG P, WEN H, OU S, CUI J, FAN D (2012). IL-6 promotes regeneration and functional recovery after cortical spinal tract injury by reactivating intrinsic growth program of neurons and enhancing synapse formation. Exp Neurol 236: 19-27.

ZENDEDEL A, NOBAKHT M, BAKHTIYARI M, BEYER C, KIPP M, BAAZM M, JOGHATAIE MT (2012). Stromal cell-derived factor-1 alpha (SDF-1 $\alpha$ ) improves neural recovery after spinal cord contusion in rats. Brain Res 1473: 214-226. 
ZHANG Y, DESAI A, YANG SY, BAE KB, ANTCZAK MI, FINK SP, TIWARI S, WILLIS JE, WILLIAMS NS, DAWSON DM, et al., (2015). Inhibition of the prostaglandindegrading enzyme 15-PGDH potentiates tissue regeneration. Science 348: aaa2340-aaa2340.

ZHAO X, WAN J, MARTIN G, GOLDMAN D (2014). Leptin and IL-6 Family Cytokines Synergize to Stimulate " Iler Glia Reprogramming and Retina Regeneration Article Leptin and IL-6 Family Cytokines Synergize to Stimulate Mu " Iler Glia Reprogramming and Retina Regeneration. CellReports 9: 272-284.
ZIV Y, RON N, BUTOVSKY O, LANDA G, SUDAI E, GREENBERG N, COHEN H, KIPNIS J, SCHWARTZ M (2006). Immune cells contribute to the maintenance of neurogenesis and spatial learning abilities in adulthood. Nat Neurosci9: 268-275.

ZUPANC GK, HINSCH K, GAGE FH (2005). Proliferation, migration, neuronal differentiation, and long-term survival of new cells in the adult zebrafish brain. $J$ Comp Neurol 488: 290-319.

ZUPANC GKH, HORSCHKE I, OTT R, RASCHER GB (1996). Postembryonic development of the cerebellum in gymnotiform fish. J Comp Neurol 370: 443-464. 


\section{Further Related Reading, published previously in the Int. J. Dev. Biol.}

Development vs. behavior: a role for neural adaptation in evolution?

Alain Ghysen and Christine Dambly-Chaudière

Int. J. Dev. Biol. (2016) 60: 77-84

https://doi.org/10.1387/ijdb.160097ag

Patterning the nervous system through development and evolution

Alain Ghysen, Christine Dambly-Chaudière and David W. Raible

Int. J. Dev. Biol. (2010) 54: S1-S14

https://doi.org/10.1387/ijdb.103182ag

Expression of protocadherin-19 in the nervous system of the embryonic zebrafish

Qin Liu, Yun Chen, Fumitaka Kubota, Jean J. Pan and Tohru Murakami

Int. J. Dev. Biol. (2010) 54: 905-911

https://doi.org/10.1387/ijdb.092882ql

Insulin-like growth factor-2 regulates early neural and cardiovascular system development in zebrafish embryos

Lori Hartnett, Catherine Glynn, Catherine M. Nolan, Maura Grealy and Lucy Byrnes

Int. J. Dev. Biol. (2010) 54: 573-583

https://doi.org/10.1387/ijdb.092922lh

Hindbrain signals in otic regionalization: walk on the wild side

Sylvie Schneider-Maunoury and Cristina Pujades

Int. J. Dev. Biol. (2007) 51: 495-506

https://doi.org/10.1387/ijdb.072345ss

Expression of FoxP2 during zebrafish development and in the adult brain Rina Shah, Olga Medina-Martinez, Li-Fang Chu, Rodney C. Samaco and Milan Jamrich Int. J. Dev. Biol. (2006) 50: 435-438

https://doi.org/10.1387/ijdb.052065rs

Development of axon pathways in the zebrafish central nervous system

Jensen Hjorth and Brian Key

Int. J. Dev. Biol. (2002) 46: 609-619

http://www.intjdevbiol.com/web/paper/12141449

Role of hlx1 in zebrafish brain morphogenesis Jensen T Hjorth, Robin M Connor and Brian Key Int. J. Dev. Biol. (2002) 46: 583-596

http://www.intjdevbiol.com/web/paper/12141447

5 yr ISI Impact Factor $(2016)=2.421$
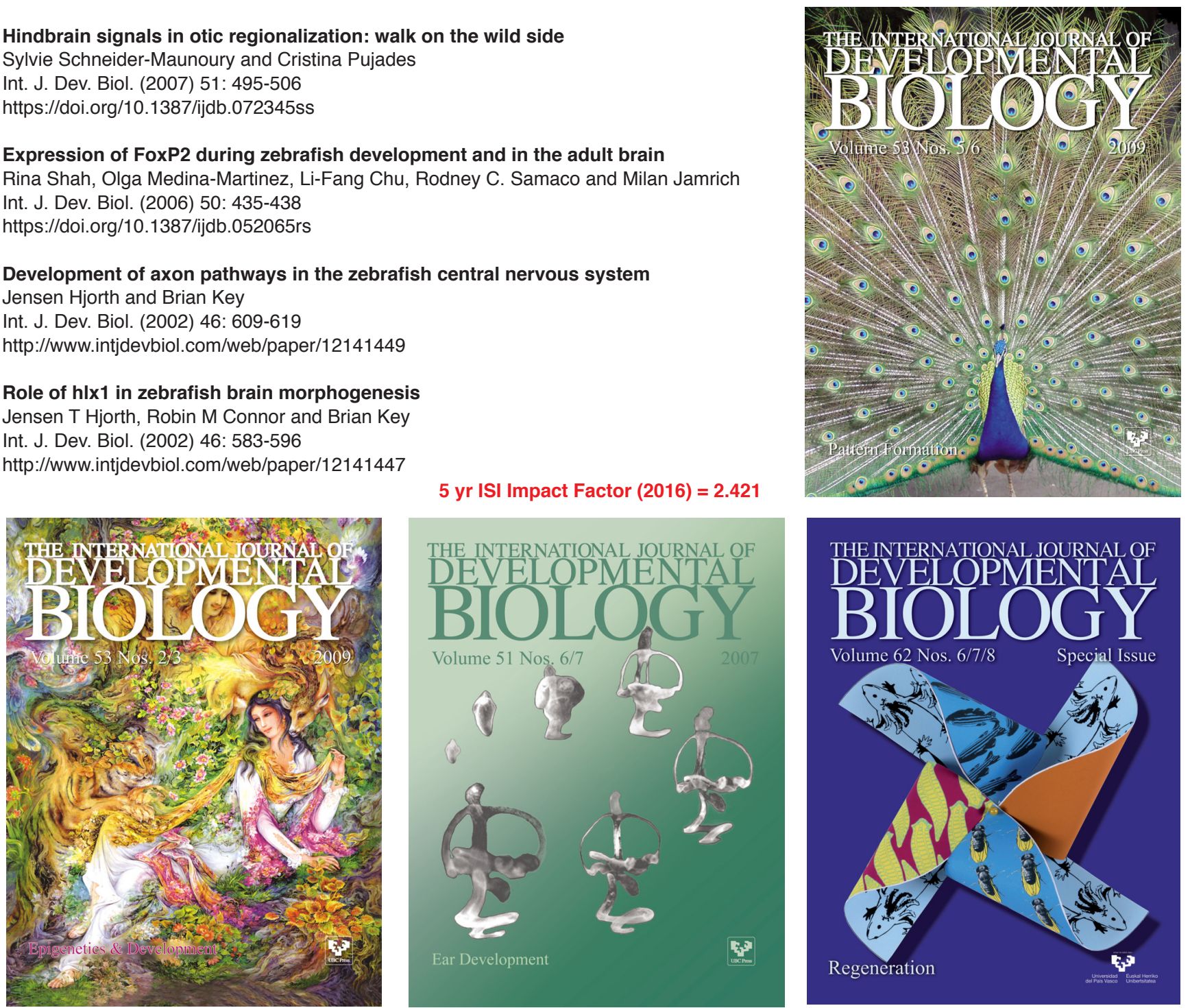